\title{
Household Archaeology in Polynesia: Historical Context and New Directions
}

Jennifer G. Kahn

College of William and Mary, jgkahn01@wm.edu

Follow this and additional works at: https://scholarworks.wm.edu/aspubs

\section{Recommended Citation}

Kahn, Jennifer G., Household Archaeology in Polynesia: Historical Context and New Directions (2018). JOURNAL OF ARCHAEOLOGICAL RESEARCH, 25(1).

$10.1007 / \mathrm{s} 10814-016-9099-2$

This Other is brought to you for free and open access by the Arts and Sciences at W\&M ScholarWorks. It has been accepted for inclusion in Arts \& Sciences Articles by an authorized administrator of W\&M ScholarWorks. For more information, please contact scholarworks@wm.edu. 


\title{
Household Archaeology in Polynesia: Historical Context and New Directions
}

\author{
Jennifer G. Kahn'
}

Published online: 23 February 2016

(C) Springer Science+Business Media New York 2016

\begin{abstract}
This review highlights archaeological investigations of precontact and historic house sites in Polynesia, a region noted for its diversity of chiefdoms in terms of scale and elaboration. Anthropological and historical perceptions of the Polynesian household have shifted over time, influencing the ways in which the household has been defined in archaeology. Early research emphasized houses as a unit of study within settlement pattern archaeology and as a means of delineating formal variability between sites and communities. Current studies stress a more holistic view of the household as a nexus of economic, social, and ritual activities. Diverse theoretical perspectives, such as the analytical concept of house societies, feminist archaeologies, landscape approaches, and agent-based models, have led to new archaeological approaches engaged with both the material and the nonmaterial aspects of the house and, in particular, how social relations structure the household. Current prominent themes include functional identification of house sites, understanding social variability, articulation of the household with the community, and comparative analyses of social complexity.
\end{abstract}

Keywords Social variability $\cdot$ Status $\cdot$ Gender $\cdot$ Domestic ritual $\cdot$ Site proxemics . House society

\section{Introduction}

Within the last four decades, the household has become an important context for archaeological analyses worldwide. Household archaeology focuses on the microscale organization of space and human activities as a means of retrieving

Jennifer G. Kahn

jgkahn01@wm.edu

1 Anthropology Department, College of William \& Mary, Washington Hall, Room 103, 241

Jamestown Rd., Williamsburg, VA 23185, USA 
information about prehistoric subsistence and adaptation, patterns of social organization, and the nature of social relations and symbolic behavior. Household archaeology engages with a range of material culture, including the house, its content (artifacts, subsurface features, microresidues), its exterior areas, and their spatial relationships. While the social boundaries of the household do not necessarily correlate with the physical boundaries of the dwelling (or house) (Lawrence and Low 1990), houses are physical structures where residential and social activities take place. They are found in ancient societies worldwide, facilitating both detailed, local scale analyses and broadly comparative studies.

Early household archaeology developed out of processual frameworks that proposed households as "building blocks" or adaptive, functional units with four main goals: production, distribution, transmission, and reproduction (Wilk and Rathje 1982). Processual studies focused on economic production and social reproduction at the household scale to understand community and regional-scale adaptations and the dynamics of economic and sociopolitical organization (Ashmore and Wilk 1988; Flannery 1976; Rathje and McGuire 1982; Sullivan 1989; Wilk and Rathje 1982). Since the late 1980s, household archaeologists have utilized varied social perspectives (house society models, feminist theories, landscape approaches, agency theory, etc.) to engage in a postprocessual manner with households as loci of dynamic human relationships (Robin 2003). As household archaeology broadened its focus from a narrow economic view to one engaging households as loci of social relations, new topics of research emerged. Such studies investigated how households varied in social identity or domestic production and how this variability related to human action and social relations (Beaudry 1989; Deetz 1982; Marshall 1989; Tringham 1988).

Greater attention to intrahousehold relationships from the late 1980s onwards positioned the field to explore household organization and social production in a more detailed manner. For example, understanding the changing use of space-both within domestic architecture and activity areas-became critical to interpreting how residential social groups enlarged, contracted, or modified through time (Banning and Byrd 1989; Byrd 1994; Crown 1994; Frankel and Webb 2006; Inomata and Stiver 1998; Marshall 2000). Importantly, postprocessual critiques turned earlier models of the household as adapting to economic or political change (filtered down from the regional or community level) on their head. The household is now viewed as a context of daily practice, a window into the lives of a range of past peoples, including commoners, and a significant source of social change that researchers investigate through the study of internal dynamics, domestic social relations, common investments in residential activities, and interrelationships among households (De Lucia and Overholtzer 2014; Hendon 1996; Joyce 2000; Tringham 2012; Ur 2014).

Household archaeology has become a fundamental methodology for archaeological research on the sociopolitical and economic organization of complex societies (Allison 1999a, 2004; Douglass 2002; Flannery and Marcus 2005; Robin 2003; Rogers and Smith 1995; Wattenmaker 1998). Investigating variability in residential space, artifacts, and activities provides a "bottom-up" approach to past societies that emphasizes the daily practice and activities of ordinary people, a 
perspective not offered by regional “top-down" studies (Allison 1999b; D' Altroy and Hastorf 2001; Hendon 1996, 2004; Kirch and Sahlins 1992a, b; Robin 2004). The household likewise provides a context for investigating the reproduction and materialization of social difference and social inequality through daily practice (Coupland 2013; Hendon 2010; Kristiansen 2013). Such studies highlight variation in production and consumption activities at the household level in order to identify the organization of domestic production and labor, and relations of inequality at the micro- and community scale (Allison 1999a, b; Ames 1995; Blanton 1995; Dueppen 2015; Hendon 1996, 1999; Janusek 2005; Pope and Pollock 1995; Vaughn 2004).

As with worldwide studies, anthropological and historical perceptions of the Polynesian household have shifted over time, influencing the ways in which the household has been defined in archaeology. Shifts in archaeological practice have affected the types of research questions asked and the types of data emphasized in household archaeology research. In Polynesia, diverse theoretical perspectives, such as the analytical concept of house societies, have led to new archaeological approaches engaged with both the material and the nonmaterial aspects of the house and, in particular, how social relations structure the household. In this review, I provide a discussion of advances in Polynesian household archaeology over the last 30 years. As it serves as the first major review of Polynesian household archaeology, I survey earlier research from the 1960s onwards. My main focus is on the prehistoric period prior to European contact, but I discuss select postcontact studies. In the thematic section that outlines major themes within Polynesian household archaeology, I narrow the focus to East Polynesia where the majority of detailed household archaeology studies have been completed. I begin with an introduction to the Polynesian region before moving to a discussion of the historical development of household archaeology in the region and its current practice. Finally, I turn to major thematic concerns in East Polynesian household archaeology, including functional identification of house sites, understanding social variability, articulation of the household with the community, and comparative analyses of social complexity.

\section{Cultural and Geographical Background to Polynesia}

The term Polynesia-many islands-was first penned by the French European explorer D'Urville (1832) in a racist classification where he differentiated the region from Micronesia-little islands-and Melanesia_dark islands-referring to the generally dark skin of its resident cultures. Polynesia still functions as a geographic term for islands and cultures in the easternmost extent of the Pacific Island or Oceania region. It also refers to a meaningful historical unit, as all Polynesian cultures share a common history and derive from common ancestral cultures (Kirch and Green 2001). All Polynesian languages fall within the Oceanic subgroup of the Austronesian language family. The Austronesian language family contains clear internal relationships and has been well associated with the late Holocene Lapita settlement of West Polynesia and the post-Lapita settlement of East Polynesia. Within Polynesia, there has been a long tradition of utilizing archaeology, historical 
linguistics, bioanthropology, and ethnohistory, notably oral traditions and European explorers' accounts, as independent datasets to form integrative models of island colonization, regional differentiation, and social complexity. Household archaeology studies in the Polynesian region have clearly benefitted from such holistic analyses.

The archipelagos of East Polynesia span the geographical triangle delimited by the Hawaiian Islands, Rapa Nui (Easter Island), and Aotearoa (New Zealand) (Fig. 1). They were settled from an ancestral homeland in West Polynesia that includes the high island archipelagos of Tonga and Samoa. Colonization of East Polynesia required a range of adaptations to specific island environments, including large resource-rich high islands, smaller resource-poor atolls and coral (makatea) islands, and continent-like landmasses (New Zealand). East Polynesian islands vary in their degree of isolation and climate. While most islands lie within the tropical to subtropical zone, Aotearoa has a temperate climate, necessitating agronomic adaptations. Polynesian societies were based on agriculture, cropping, and tending a suite of domestic plants and animals. Yet in temperate Aotearoa, many crops could

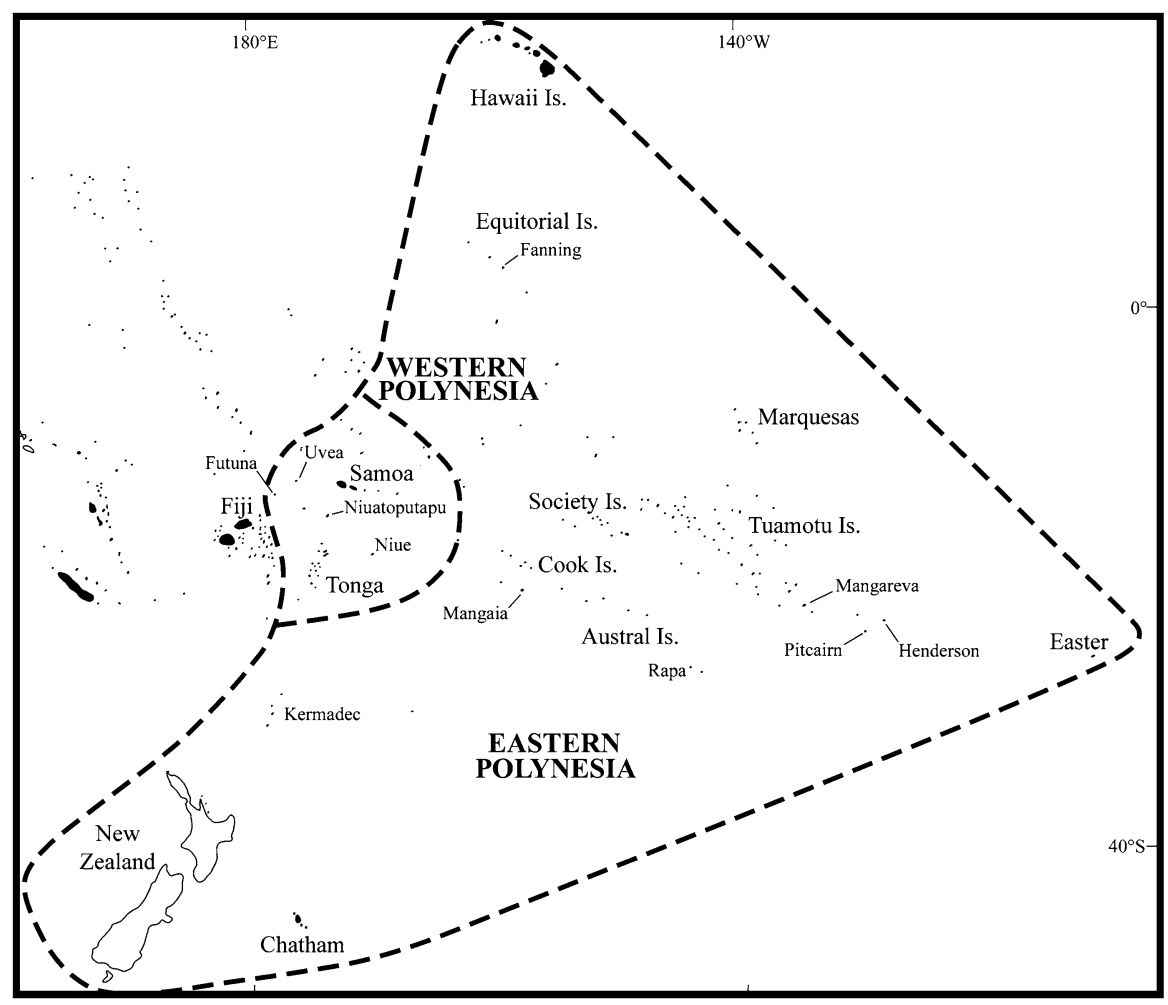

Fig. 1 Location of the East Polynesian triangle and its relationship to West Polynesia. Bold text shows main cultural areas, larger font designates major island chains and archipelagoes, smaller font designates individual islands 
not flourish, and in the colder southern regions, the Maori shifted to hunting and gathering.

At European contact, Polynesian cultures were organized as chiefdom societies; however, much variation existed among island groups. Polynesian archaeologists and ethnographers typically classify the region's chiefdoms using Sahlins's (1958) model of hierarchy and stratification (simple, mid-range, complex) or Goldman's (1970) status rivalry classification (traditional, open, stratified). Simple chiefdoms lacked formalized status distinctions, were mainly structured around kinship principles, and were often found on smaller islands with limited resources (atolls). Chiefly power rested on carrying out sacred and secular duties. Open societies saw the advent of secular power (military and political), with intense competition between different social groups and categories such as junior ranking elites and warriors. Such societies were generally present on mid-sized islands and had two or more levels of chiefs. Complex chiefdoms developed only in the large, resource-rich high island archipelagos, including Tonga and the Society Islands. In these societies, chiefs had far-reaching sociopolitical and religious authority, which created remarkable status differences between the chiefly and commoner classes. Recently, researchers (Hommon 2013; Kirch 2010) have argued that the Hawaiian Islands, once thought to be the most complex Polynesian chiefdom, evolved into an archaic state with highly formalized class distinctions and a separate endogamous class of god-kings. Although a number of archaeologists have warned against the construction of "ideal types" that pigeonhole diversity found in prehistoric societies (Beliaev et al. 2001; Chapman 2003; Drennan et al. 2012; Drennan and Peterson 2006; Pauketat 2007; Yoffee 1993), the simple-open-complex chiefdom schema has allowed Polynesian archaeologists to identify key social and environmental processes (island size, isolation, natural resources, nature of chief's leadership role, sources of chiefly power, role of status rivalry, demography, redistribution, etc.) that may underlie historically based local trajectories (Earle 2011; Hommon 2013; Kirch 2000; Kolb 2012).

East Polynesia is a region notable for its shallow chronology. Although still debated, earliest settlement was likely c. 1,100 years ago from a homeland in West Polynesia (Conte and Molle 2014; Kahn et al. 2015b; Kirch 2011), with the last islands and archipelagos settled as late as c. AD 1280 (Wilmshurst et al. 2008). This short chronology allows us to track changing household dynamics up until the period of European contact (in many archipelagos the last quarter of the 18th century). Because all East Polynesian cultures are derived from common ancestral societies in West Polynesia (Kirch and Green 2001), archaeologists can observe shared patterns in the conceptualization and materialization of domestic practices and how these shifted through time. Of particular interest is the post-AD 1400 period, when island groups became increasingly isolated after long-distance exchange spheres retracted, intra-archipelago interaction was minimized, and the development of regional styles flourished (Kahn 2014a). During the post-AD 1400 period, housing styles became more differentiated at the local level. The formalization of household rank and status and occupational specialization, and how the three articulate with community socioeconomic processes through time and 
space, likewise facilitate cross-cultural comparisons throughout the short East Polynesian temporal sequence

Of particular note is how the concept of tapu-a series of social proscriptions shared among all Polynesian societies-was more formalized in open and complex chiefdoms. At European contact, the broadest social division in Polynesian cultures was between persons of low status versus persons of high status. Those of high status had more mana (sacred power one is born with), which had to be protected by keeping persons, items, or activities considered sacred separate from those considered profane (Shore 1989). At the most basic level, this necessitated that Polynesians kept cooking areas (considered dirty or profane) separate from sleeping areas. At the most highly elaborated level, tapu restrictions greatly affected all aspects of daily life. For example, certain high-status foods and activities were restricted to the elite, while men and women, at least those of high rank, had to cook and eat foods separate from one another. In the Society Islands, commoners had to bear their heads and shoulders as a sign of respect when in the presence of chiefs. Commoners likewise had to avoid walking on the ground that chiefs walked on, effectively excluding them from frequent interaction with the elite. However, the extent to which tapu restrictions, and adherence to them, might vary in time and space and with the degree of regional sociopolitical organization provides other fruitful comparative avenues for Polynesian household studies.

\section{Household Archaeology in Polynesia: History and Methods}

In the 1960s, Green (1967; Green and Davidson 1969; Green et al. 1967) introduced the settlement pattern approach to Polynesian archaeology. Since then, settlement pattern studies have been a dominant theme of archaeological research in the region (Morrison and O'Conner 2015). Household archaeology was conceived as one of three levels of analysis within settlement archaeology to access past social and political systems (Trigger 1967, p. 151). Polynesian settlement pattern studies of the 1970s-1980s typically were applied at the regional community level (Green 1984, p. 64) and were associated with intensive survey and excavations, providing distributional data on the range of site types across a broad landscape (e.g., Bellwood 1972, 1978; Clark and Herdrich 1993; Green and Davidson 1969, 1974; Green et al. 1967; Jennings and Holmer 1980; Kirch 1998; Kirch and Kelly 1975; Ladefoged et al. 1987; McCoy 1973, 1976; Tuggle and Griffin 1973). Many of these studies incorporated excavations of house structures as a "level of analysis," following Wilk and Rathje (1982).

In settlement pattern archaeology in Polynesia, households, as one element of the overall archaeological landscape, became a unit of study for delineating formal variability between sites and communities. Many of these projects took a functional and processual approach to document human adaptations to different environments (a settlement-subsistence approach). Other works, however, investigated the interplay between spatial variation in settlement layout and sociopolitical organization, in an attempt to define inter- and intracommunity status and rank among 
communities (a settlement-social organization approach) (Green 1967, p. 102; see discussion in Green 1984; Kirch 1996).

Throughout the late 1960s, 1970s, and 1980s, several large-scale archaeological projects in West and East Polynesia incorporated the analysis of house sites within holistic research designs that integrated varied lines of evidence. Green and Davidson's $(1969,1974)$ settlement pattern research in Western Samoa included survey, surface mapping, and areal excavations at a limited number of residential sites. Their study demonstrated successive house foundations within the same house platform, allowing for inferences of changing house design over time (Fig. 2). Transformations in the social organization of the household were indicated by shifts from subhouse burial to exterior house burial in platforms (Ishizuki 1974, pp. 30-31). Variation was found in the spatial layout of activities, including evidence for pit features, perhaps for fermenting foodstuffs, associated directly with houses in the earlier periods (Davidson 1974a, p. 237) and to a lesser extent in the later periods, and a shift from shallow informal hearths to formal slab-lined hearths (Davidson 1974a, p. 232). Pebble pavements consistently defined the house interior

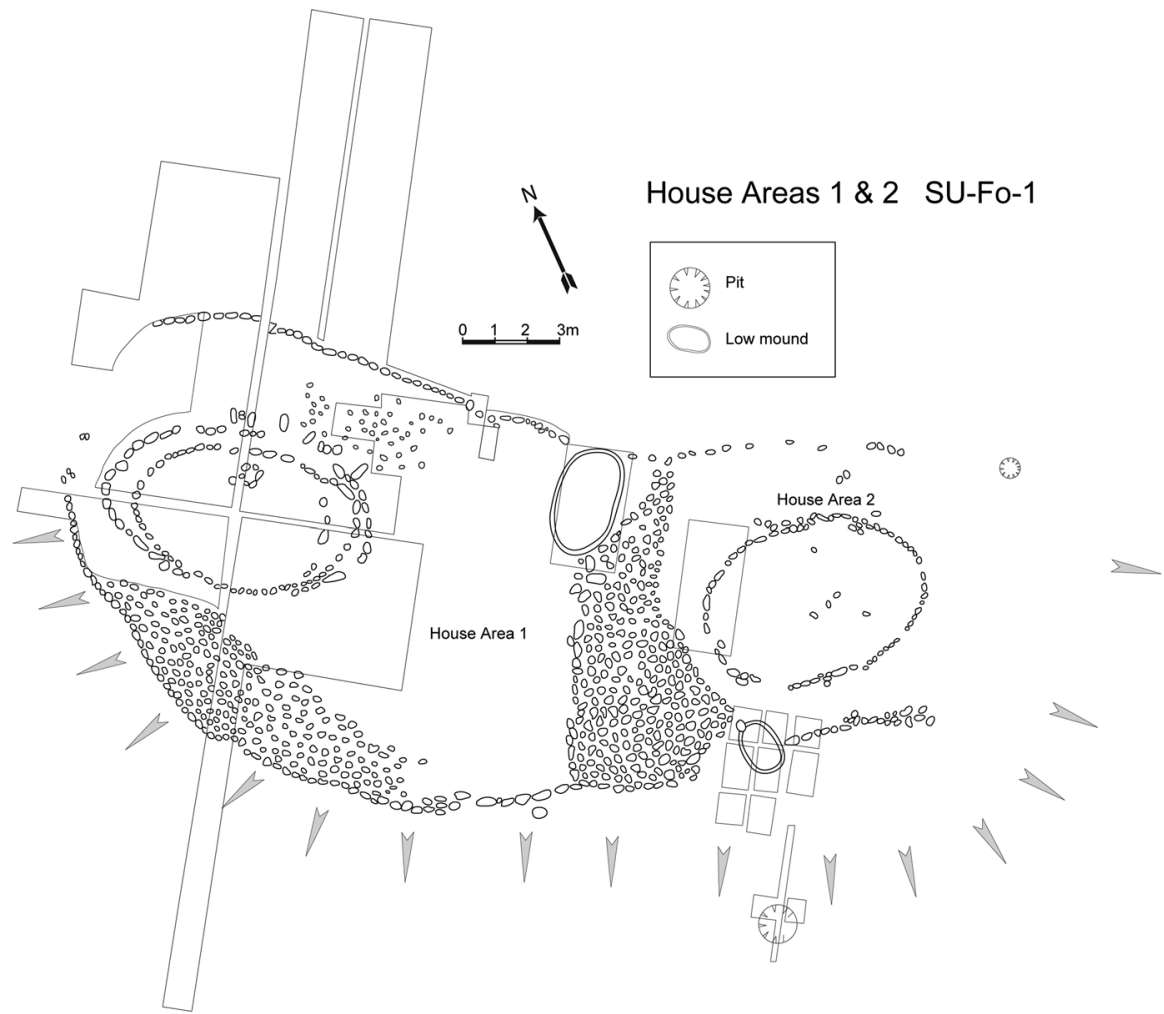

Fig. 2 Excavated houses Su-Fo-1 and 2, Folasa-a-Lalo, Samoa (after Green and Davidson 1969). Houses are delineated by curbstone outlines and have interior pebble paving; exterior pavements are constructed from larger stone 
throughout the sequence. While their methodology of excavating only half of each house structure ultimately limited their interpretations, Green and Davidson illustrated the efficacy of horizontal household excavations for establishing variation in the form of precontact Samoan house sites. Notable was the plethora of subsurface features and artifacts associated with house architecture and their changing relationships through time.

Jennings and colleagues (Jennings and Holmer 1980; Jennings et al. 1976) built on Green and Davidson's research and carried out detailed survey and mapping at Mt. Olo village in Upolu, Western Samoa, where spatial patterning led to the definition of the household unit as the recurring primary unit of settlement (Jennings and Holmer 1980, p. 3). The household unit was defined as an area largely enclosed by walls and paths, with at least one large $\left(>10 \times 10 \mathrm{~m}^{2}\right)$ or two small $(<10 \times 10$ $\mathrm{m}^{2}$ ) stone platforms or mounds (Jennings and Holmer 1980, p. 30). In their study area, household units were manifested as repeated patterning in architectural features, including large upraised stone residential platforms divided from one another by paths and walkways and associated with clear open spaces. Smaller platforms at the rear of the main residential platforms were tentatively identified as craft activity areas or cookhouses. Excavations recovered subsurface burial pits below the house platforms and food storage pits exterior to the primary dwelling. Overall, Jennings and Holmer's household excavations suggest considerable continuity in Samoan house form over time. Throughout the Samoan sequence, high-status dwellings were associated with larger floor areas and raised platforms (Green 2002, p. 142) and were spatially associated with primary walkways and perhaps guest houses (Jennings et al. 1982).

Because the excavation of Polynesian house sites was first embedded within regional-scale settlement pattern approaches, true household archaeology was not the norm during the 1960s and 1970s. In his review of Polynesian settlement pattern research, Green (1984, p. 64) stressed the need for study at all levels of analysis and noted the continued lack of "micro" or within-site analysis. While the regional scale of these early studies was often ill suited for in-depth analyses of households (Van Gilder and Kirch 1997, pp. 46, 49), these early works began to outline the material correlates of primary residences and their auxiliary structures through partial or complete excavation of limited numbers of residential structures. Polynesian settlement pattern studies were equally influential in documenting a surprising degree of inter- and intra-residential cluster variability, laying the important groundwork for later microscale studies of household variability. For example, in Hawai'i, excavations completed as part of regional settlement survey research designs have identified field shelters, rock shelters, and various alignments (Cshapes, L-shapes, U-shapes, box shapes) as temporary shelters that were used while people worked in agricultural plots or gathered coastal resources; others functioned as extended-use residential sites (Green 1980, pp. 2, 41; see discussion in Kirch 1985). Linguistic reconstructions (Green 1986) began to document expected house forms, with both straight-sided and round-ended dwellings reconstructed from the lexical data (see Kirch and Green 2001).

With the dominance of cultural resource management (CRM) archaeology in New Zealand and Hawai' $i$ since the 1970s, horizontal excavations have been largely 
ignored in favor of vertical test pits. Today, for the most part, the detailed study of precontact house sites in Polynesia is commonly carried out as part of household archaeology research by academic institutions and not as a part of CRM-based settlement pattern studies.

Fig. 3 Residential complex F, Kawela, Moloka'i, interpreted as a dwelling of a craftsman. The primary residence is associated with dense lithic reduction debris (redrafted from Kahn 2014b, after Weisler and Kirch 1985 , p. 143 , fig. 7)

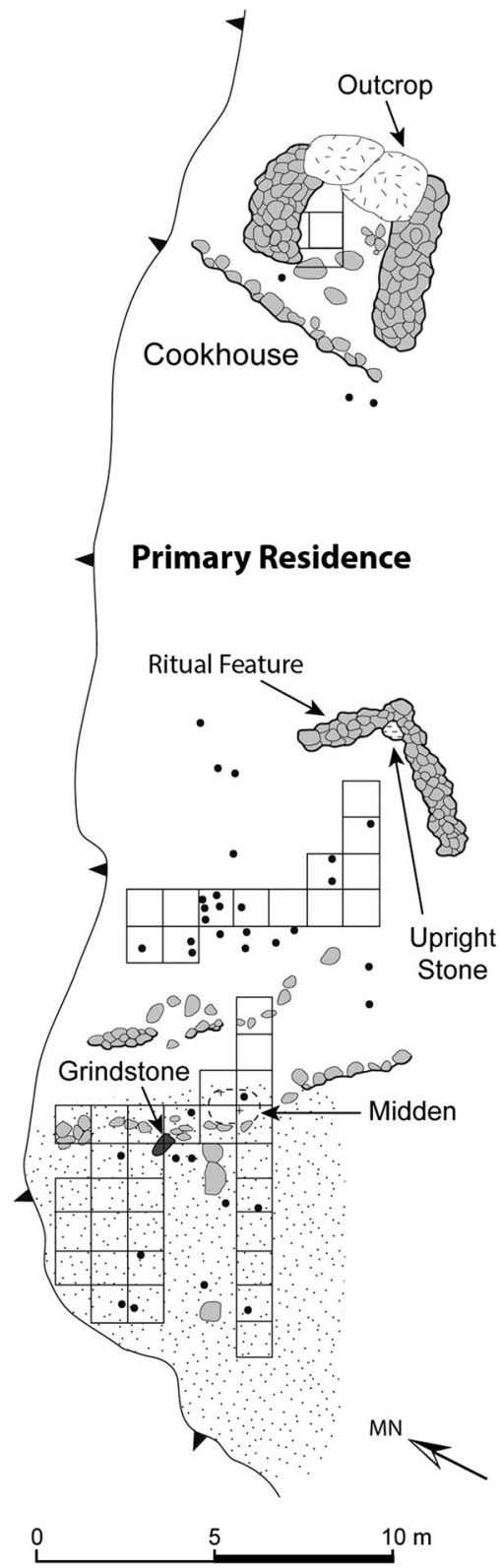




\section{Household Archaeology in Polynesia: Research Themes}

Within the last three decades, researchers have focused explicitly on the microscale level of households as a fundamental aspect of archaeological analysis in Polynesia (Anderson 2001; Kahn 2003, 2005; Kirch and O'Day 2003; Kirch and Sahlins 1992b; Oakes 1994; O’Day 2002; Sutton 1990a; Taomia 2000; Van Gilder and Kirch 1997; Walter 1993; for an early exception see Weisler and Kirch [1985], discussed below). Weisler and Kirch's (1985) study of the "structure of settlement space" within households and communities at Kawela, Moloka“i, was a revolutionary departure from the functional approaches taken by most prior studies. Weisler and Kirch advocated the use of four complementary paradigms for analyzing Polynesian settlement patterns: environmental, social, economic and political, and semiotic. Their goal was to document the archaeological correlates of ethnohistorically documented features within Hawaiian house clusters (primary residences, temporary habitation shelters, cooking sheds) and to test ethnographic models of idealized Hawaiian households (e.g., Handy and Pukui 1972). Their work critically identified diverse aspects of material variation in precontact Hawaiian house clusters. For example, the primary residence was often the largest structure in the residential cluster and included stone uprights as domestic ritual features, cupboards, and slab-lined hearths (Weisler and Kirch 1985, pp. 142-147). The surrounding ancillary structures exhibited a range of forms, including low short walls or informal $\mathrm{C}$, J, and L-shaped shelters, some associated with lithic reduction activities (Fig. 3). In Kawela, elite residences were extensive, incorporating a greater number of structures per household cluster. They also were associated with formal temples and had prominent topographic settings.

Following Weisler and Kirch, an emerging and growing field within Polynesian archaeology is the study of precontact variability in residential sites and variability within and between household clusters. Recent studies derive mainly from precontact East Polynesian contexts, with research carried out in the Society Islands (Kahn 2003, 2005, 2007; Kahn and Kirch 2004, 2013; Oakes 1994); the Cook Islands (Endicott 2000, 2002; Taomia 2000; Walter 1993, 1998, 2004); the Marquesas Islands (Allen 2009); New Zealand (Sutton 1990a, 1993; Sutton et al. 2003); Norfolk Islands (Anderson and Green 2001); and Hawai'i (Field et al. 2010; Kahn 2014b; Kirch 1998; Kirch et al. 2010; Van Gilder 2001; Van Gilder and Kirch 1997). Comprehensive historic period household archaeology projects are limited to the Hawaiian archipelago and New Zealand (see Anderson 2001; Flexner 2010, Jacomb 2005; Kirch and Sahlins 1992b; Middleton 2003, 2007, 2009); many of these data are in the unpublished gray literature (e.g., Klieger and Lebo 1999; for New Zealand see Smith 2004).

Recent East Polynesian studies apply microscale techniques of household archaeology to understand variation in domestic organization and its relationship to culture change. Broad horizontal excavations of house interiors and exterior areas have allowed for precise temporal and spatial control, increasingly accurate functional interpretations of domestic structures, and identification of zones used for domestic rituals. Other microscale techniques, including close attention to 
stratigraphy, use, and construction events (Field et al. 2011; Sutton et al. 2003), distribution patterns of macroartifacts and macrobotanicals (Endicott 2000; Kahn and Ragone 2013; Marshall and Fulton 1987; Oakes 1994; Walter 1998), and microfossil analyses of artifact residues and sediments in subsurface pits, cooking features, and on domestic tools (Allen and Ussher 2013; Kahn et al. 2014; Horrocks and Wozniak 2008; Weisler and Haslam 2005), have provided more accurate identification of domestic activities and their timing on the landscape, in addition to evidence for mundane, everyday events.

A much wider variety of scientific techniques are now commonly applied to household contexts in East Polynesia, similar to patterns in household archaeology worldwide (Estévez Escalera and Clemente-Conte 2013; King 2008; Kovács 2013; Robin 2003; Ullah et al. 2015). For example, Kahn and Ragone (2013) discuss excavations at a round-ended house in the Society Islands where systematic flotation of subsurface feature contents allowed for the recovery of small carbonized fragments of breadfruit (Artocarpus altilis) exocarp. These data confirmed the antiquity of breadfruit roasting over open fires in the past, as well as the specialized nature of this particular house site. In the Hawaiian archipelago, researchers have applied Uranium-Thorium dating to develop highly precise chronologies of domestic site construction and use (Weisler et al. 2006). Others have developed relative chronologies through architectural construction phases and have tested these models with Bayesian analysis of radiocarbon dates derived from residential complexes (Field et al. 2011), similar to worldwide studies (Overholtzer 2015).

East Polynesian household archaeology in the 1990s and 2000s engaged varied theoretical perspectives and a dynamic view of culture. Researchers highlighted that numerous social processes, including gender, wealth, craft specialization, and rank and status inequalities, contribute to the diversity of domestic material remains. Social diversity can be expressed in subsistence remains and foodways (Field et al. 2010; Kirch and O'Day 2003), the use of house interior and exterior space (Endicott 2002; Kahn 2005, 2007; Kirch 1996; Law 1999; Sutton 1990d; Van Gilder and Kirch 1997), and the presence and intensity of production activities (Kahn 2005; Kolb 1999; Walter 1998, 2004).

Current household archaeology in Polynesia stresses a more holistic view of the household as a nexus of economic, social, and ritual activities, similar to worldwide perspectives (De Lucia and Overholtzer 2014; Hendon 2004). Research questions have broadened, necessitating detailed, extensive areal excavations of both the interior and exterior spaces of structures to identify site chronology, the range of household features, the spatial distribution of activities, the organization of domestic space, and site function (Endicott 2000; Oakes 1994, pp. 71-72; Pigeot 1987; Sutton 1990a; Van Gilder and Kirch 1997, p. 49; Walter 1993, pp. 80-83). Walter's (1993, 1998, 2004) detailed research on Archaic period household sites in the Cook Islands differentiated cooking zones from manufacturing areas with artifact distributions and intrasite analysis. Walter linked differences in the organization of activity areas, household production, and other domestic tasks to public versus private space. Ladefoged (1998) documented similarities in the use of space within royal temples, household clusters, and individual house sites in the Hawaiian Islands and argued that the relative spatial positions of architectural elements commonly found in these 
three site types are predicated on the observance of the kapu (Hawaiian gloss for tари) system and ritual offerings. In the Society Islands archipelago, Oakes (1994) and Kahn $(2003,2005)$ investigated architectural elaboration, in addition to traces of daily mundane life, such as activity areas and the use of interior and exterior space, to differentiate elite habitations from commoner house sites. Their studies illustrate the importance of daily activities for understanding diversity in precontact social status at the microscale. The proximity of cooking features to the house and their size, form, and degree of formalization were indicative of household rank (Kahn 2005, p. 325).

Understanding internal social relations and symbolic aspects of the household has become a definitive goal of household archaeology in East Polynesia (Endicott 2000; Kahn 2014b; Oakes 1994). Kirch (1996) describes this shift as an initial focus on the external determinants of spatial patterning and land use that gave way to an increased interest in the internal causes of social change at the local level. While there are still few projects, researchers have successfully correlated residential architecture, house plans, and spatial organization to social relations, customs, and, to a lesser extent, the underlying order or ideology (Endicott 2002; Kahn 2007, 2014b; Kirch 1996; Oakes 1994; Prickett 1982; Sutton 1990a, d; Weisler and Kirch 1985). Such studies have utilized large horizontal exposures of house floors and surrounding areas to complete detailed spatial analyses. Particular attention has been paid to the spatial arrangement of subsurface features, artifacts, and activities (e.g., cooking, storage, ritual features, etc.), their proximity to the house structure, auxiliary structures, and surrounding house structures, and their alignment with cardinal points, particularly those with ritual significance. These recent studies emphasize that the household is "semiotically organized in culturally meaningful ways" (Kirch 1996, p. 270), in other words, a social context where human relationships are negotiated.

While East Polynesian household archaeology in the 1990s and 2000s adopted the broad-scale horizontal exposure method that dominates household archaeology worldwide, the last decade has seen a closer fit of microscale techniques to projects that de-emphasize broad-scale excavations. For example, at Kohala, situated in a coastal zone on Hawai'i Island with excellent bone and shell preservation, large horizontal exposures are not allowed due to the sheer time and effort it takes to screen midden deposits replete with faunal remains. In such locales, microscale analyses of smaller block excavations have recovered subsurface features and artifact assemblages that have been subjected to detailed analyses, resulting in interpretations about household rank, status, and access to resources (Field et al. 2011; Kahn 2014b; see Weisler et al. 2006 for another Hawaiian example). This work echoes the innovative use of limited sampling data found in household archeology in other parts of the world (Pluckhahn 2010).

\section{Social Variability}

While informed by ethnohistoric records, microscale household studies contribute empirical data to understanding variation in precontact Polynesian societies, including evidence for shifts in social relations and production activities that went 
hand in hand with increasing sociopolitical complexity in Polynesian chiefdoms. In fact, an emerging pattern from Polynesian household archaeology is that data from excavated precontact houses typically exhibit more variation than expected from the historical records (Kahn 2003; Oakes 1994; Taomia 2000; Van Gilder and Kirch 1997), likely because of the lack of temporal and regional variation present in the ethnohistoric data and the idealized nature of many of the historic descriptions.

Recent applications of household archaeology in Polynesia have established significant variation among precontact Polynesian households. Diversity in various aspects of precontact house sites have been proposed, including the quality and elaboration of household architecture, the number and type of adjacent structures, site proxemics within the complex, and the presence, intensity, and arrangement of subsurface features, artifacts, and activity areas. Intrasite variation is now believed to be associated with varied factors and not linked solely to status or environmental factors, as many early processual studies had claimed (e.g., McCoy 1973). The organization of local production, degree of specialized activities, duration of site use, and developmental cycle of the household group can contribute to inter- and intrasite variation, although variation linked to rank differences and inequality continue to the foci of much Polynesian household research.

\section{Social Rules and the Use of Interior Versus Exterior House Space}

Researchers have established varied patterns of the use of space within precontact Polynesian households related to several factors, including the types of activities carried out, the nature of site use (as a sleeping house, specialized activity area, or craft locale), as well as the status of the occupants (Endicott 2000; Oakes 1994; Walter 1998). Elite households and ritual contexts should have a more formalized use of interior and exterior space, given the need to follow social prescriptions (tapu), which are widespread throughout Polynesian societies (Kahn 2007, 2014b; Kahn and Kirch 2014).

Cross-culturally, household archaeology in East Polynesia has illustrated broad adherence to social rules that dictate the cookhouse or cooking features should be separated from the main sleeping house, which supports ethnohistoric documentation (Best 1924, p. 93; Buck 1930, pp. 13-14; Dixon et al. 2008; Endicott 2000; Irwin 2004, p. 65; Kirch 1996; Prickett 1982, pp. 132-139; Sutton 1983; Walter 1998, 2004). Green (1986) argued that these components can be reconstructed to Ancestral Polynesian society, with lexical reconstructions of proto-Polynesian terms for house, *fale, and cookhouse *fale 'umu.

Although the primary residence and separate cookhouse are shared features throughout Polynesia, there is considerable variation in primary residence form and the number and form of ancillary structures at the level of the society. Primary dwellings can be found on flat surfaces or earthen terraces, with earthen floors (e.g., New Zealand, Society Islands) or sometimes demarcated by stone or wood curbing (e.g., Society Islands, Samoa). Alternatively, they are found on earthen mounds (e.g., Tonga) or on stone pavements or stone platform foundations (Cook Islands, Marquesas Islands, Society Islands). Some precontact New Zealand dwellings are semisubterranean, likely an adaptation that allowed residents to stay warm in severe 
weather (Marshall 1990; Sutton 1990d). In most areas, primary dwellings are associated with small hearths (e.g. Society Islands, Marquesas Islands) or welldemarcated slab-lined hearths (e.g., Hawai'i, New Zealand) used for warmth or bug removal rather than for cooking. Society Island studies have noted that the specific proximity of the cooking feature to the house as well as its size and form is indicative of household rank. Elite residences had larger and more formally separated cooking sheds located on terraces and living flats formally detached from the house, whole lower-status residences had smaller cooking features in closer proximity, sometimes directly attached to house walls (Kahn 2005, 2007; Kahn and Kirch 2013; Oakes 1994, p. 76).

\section{Status}

A continuing focus of Polynesian household archaeology is the investigation of variation among and between precontact commoner and elite houses of varying status. Early processual studies (Cordy 1981; McCoy 1973) emphasized the use of rare or valuable materials in surface architecture, the size and height of the house structure, and the degree of architectural elaboration as proxies for labor expenditure. Greater labor expenditure in house construction was interpreted as a measure of elite household status, similar to cross-cultural studies of house architecture in other prestate societies (Feinman and Neitzel 1984, p. 75). These initial Polynesian studies focused primarily on the most visible and durable surface remains.

In a later discussion of household rank and status, Weisler and Kirch (1985, p. 148) advocated for the use of multiple lines of evidence, arguing that simple measures such as floor area were insufficient criteria for determining household rank. They developed a model for a holistic analysis of household rank, utilizing multiple lines of evidence that include topographic setting, number of structures, type and presence of the ritual feature (whether formally separated from the primary residence or within the residence), presence of burial platforms, high frequencies of status foods such as pig and dog, high densities of shellfish and other faunal remains, high densities and types of formal artifacts, and lithic artifacts produced from nonlocal sources (Weisler and Kirch 1985, p. 148).

Today, archaeologists in Polynesia recognize the complexity of studying status at precontact house sites because of nuanced differences between and within the elite and non-elite classes. Classic elite/commoner dichotomies based on the ethnohistoric record do not always hold up during archaeological inspection (Kirch and Sahlins 1992b; Sutton 1990a), which requires that varied lines of evidence be used to investigate local expressions of status and rank difference. Site proxemics provide a particularly productive line of evidence for understanding household status in Polynesia. The spatial arrangement of house sites and their visibility, both in relation to one another and to other structures such as ceremonial temples or shrines, can be related to household status and social class (Kahn 2007; McCoy 1973; Sutton 1990b, d; Sutton et al. 2003; Walter 2004; Weisler and Kirch 1985). In the Cook Islands, differences in the size and complexity of house structures have been cited as evidence of social ranking, with larger and more complex domestic sites often 
situated closer to monumental temples sites (Walter 2004, p. 42). Similar trends have been noted in the late precontact Society Islands, where elaborate elite dwellings are situated close to temple sites and important natural resources (waterways, springs) and are among the earliest sites constructed on the landscape (Kahn and Kirch 2013). This spatial association between status, domestic structures, and religious structures mirrors links between secular power and the ritual world and confirms house society models (see later discussion) that closely link ritual power and sacredness with the dwelling and the residential group.

The location of structures within residential clusters, particularly their height and placement on the landscape, can be particularly important in investigations of household status (Field et al. 2010; Weisler and Kirch 1985). Weisler and colleagues (Weisler et al. 2006, p. 277) have proposed that high-status Hawaiian households resided in close proximity to ceremonial sites, and in high topographic settings, sometimes with commanding views of important resources such as fishing grounds or stone adze quarries. Various researchers (McCoy 1976; Vargas Casanova 1998; Wozniak 2003) have argued that elite Easter Island house sites were most commonly situated on promontories or slopes above and in close proximity to ceremonial sites and often were oriented with their entrances facing the ceremonial site. On Easter Island, elite houses are far less commonly situated inland, but when they are they are typically found on natural promontories overlooking fields, gardens, and commoner houses under elite "control" (Wozniak 2003, pp. 191, 320, 332). In a New Zealand study, Sutton (1990b, d) illustrated how precontact Pouerua house sites were oriented toward the headman's dwelling, which was the tallest house situated on the most elevated point in the complex. At certain Pouerua house sites, house form and domestic artifact assemblages were less indicative of household status than site proxemics (Sutton 1990a), further highlighting the importance of spatiotemporal analysis at the local scale. This research points toward "rapidly changing and intensifying use of space as an important hallmark of status negotiation in late precontact New Zealand settlements" (Sutton 1990d, p. 681).

Other East Polynesian archaeologists have focused on the elaboration of primary residences, including their size, form, and architecture, as indicative of household rank. In general, larger than average houses, as well as those with such elaborate architecture or distinctive design elements as coral slabs, red tuff slabs, stone carvings, stone uprights, elaborate exterior stone pavements, often in association with a series of ancillary structures, are elite residences. For example, Allen's (2010) study of the Anaho Valley in the Marquesas Islands highlighted that only a small subset of raised stone house platforms were over $100 \mathrm{~m}$ in size, suggesting that size was one factor that differentiates elite and commoner residences. These larger structures more commonly exhibited the use of fancy stonework, including nonlocal red stones used as façade and step stones. In Polynesia, elite residences also may be associated with structures not found in association with commoner residences, such as meeting houses, temple sites, and dance areas (e.g., the Marquesan tohua) (Kahn and Kirch 2014; Walter 2004).

Polynesian archaeologists presently accept that architectural elaboration alone is not sufficient to identify household rank. In some contexts, such as the Marquesas Islands, raised house platforms may be a functional adaptation to wetter conditions 
and floods in the late precontact period (Allen 2010) rather than purely a signal of elite social status. In other contexts, elite residences, specialized-use house sites of a nondomestic function, and ritual house structures can mimic one another in terms of location on the landscape, architectural elaboration, and size (Kahn 2005; Rolett 2010). In a Society Islands example, I (Kahn 2005) have argued that house form and house size, emphasized in the ethnohistoric accounts as important markers of social variability, are not useful indicators of either site function or social status at the

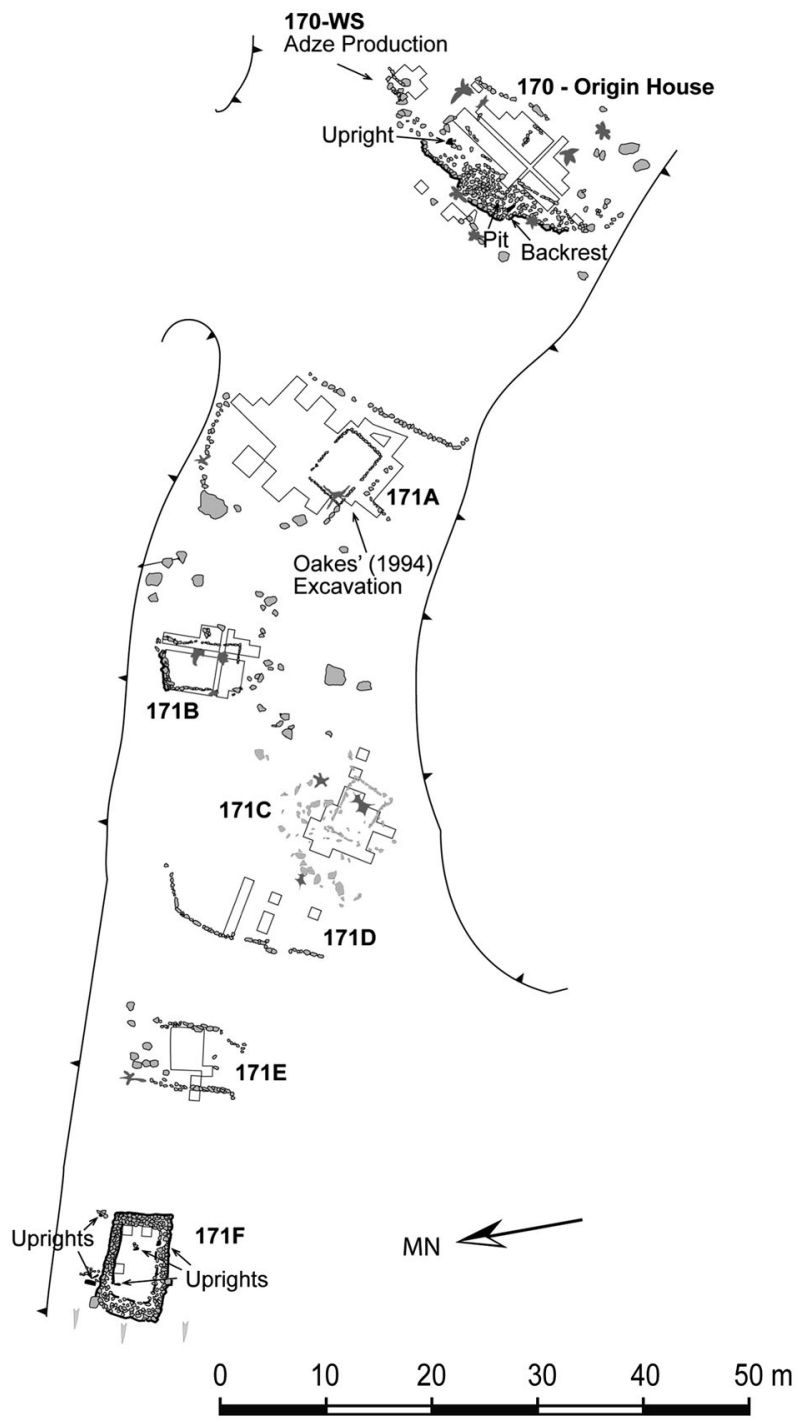

Fig. 4 Plan view of ScMo-170/171 residential complex, 'Opunohu Valley, Mo'orea, Society Islands. The 170 house is associated with an exterior adze production workshop, whereas 171A served as an indoor adze production area 
microscale when used as independent lines of evidence. In studies of the 'Opunohu Valley, the number and type of adjacent auxiliary buildings and the placement and timing of houses on the landscape were more indicative of site function, while house size and form (round-ended or rectangular) alone were not sufficient to determine house status or site function (Kahn and Kirch 2011, 2013). Certain architectural features and elaborated architectural elements, including basalt uprights, wellconstructed paved areas adjacent to the house structure, and placement of the house on an elevated and raised terrace, were good indicators of house rank or specializeduse sites. Evidence for daily activities, such as cooking, storage, lithic production, and lithic consumption (Kahn 2005, 2007; Kahn and Kirch 2013; Oakes 1994), is equally important for identifying house function or status.

Spatial studies of activity intensity have been especially useful for identifying social variability within and between households in East Polynesia. In a Cook Islands study, Endicott (2000, 2002) examined the similarities and differences in the structuring of habitation space and activities, the layout of community space, and the investment of labor as a means of investigating household status and inequality. Endicott (2000) interpreted variations in the type and intensity of activities and architectural elaboration of the house and exterior area as related to varying social personae of the household residents. She proposed that little status inequality was present in this Polynesian chiefdom of "intermediate" (i.e., open chiefdom) sociopolitical complexity, where achieved power as well as rank played a part in the often-dynamic nature of political organization. She found evidence for several social personae (wood carvers, adze makers) and differential access to labor but little evidence for interhousehold inequality. In contrast, in my study of commoner and elite houses on Society Island, I found substantial variation in production and consumption activities between the house sites. Of particular note, an exterior adze production workshop (170-WS, see Fig. 4) and interior craft area (ScMo-171A) were directly associated with a high-status residence (ScMo-170), while lowerstatus dwellings in the same complex (ScMo-171B, C) engaged in adze use and maintenance activities (Kahn 2005, pp. 418-419). In this way, the production of material goods, such as stored foodstuffs, adzes, or barkcloth, can be seen as common investments in the landed estate, allowing some households to excel in their abilities to produce surplus and material goods used in gift exchange and as tribute offerings in ritualized ceremonies (Field et al. 2010; Kahn and Kirch 2013; Law 1999). Such studies also hint at the productivity of inter- and intra-archipelago comparisons of household status. While Cook Islands studies suggest little intrasite variation in terms of household status, which supports models of "open" societies where rank and status are less highly elaborated than in complex chiefdoms, research in the "open" society of the Marquesas Islands highlights significant competitive displays of wealth, status, and power in the elaboration of house platforms in the late precontact period (Allen 2010). Certainly in current East Polynesian datasets, household status seems most elaborated in the most "complex" chiefdom of the Society Islands and the Hawaiian archaic state. Hence, there is variation in how status is expressed materially at the local level not only between chiefdoms with varying elaboration of social hierarchies (simple, open, complex) but within particular categories as well (i.e., within "open" chiefdoms). Additional 
broadly comparative work within the region would be beneficial as a means for identifying social processes that underlie cultural transformations at the local and community scales.

The extent to which access to material goods, particularly nonlocal goods, serves as a sign of household wealth and status is an ongoing debate in East Polynesia. Some Hawaiian studies have argued that access to fine-grained basalt sources for making stone tools (Kirch 2010; Weisler and Kirch 1985) or to subsistence resources such as prime fishing grounds (Weisler et al. 2006) was restricted and thus symbolized household status. However, the degree to which status is indexed by material culture diversity varies by local context (see Kirch and Sahlins 1992b, p. 174), as does the specific ways in which it is materialized. In a study of Mo'orea in the Society Islands, Kahn et al. (2013) found that adzes and adze-related debris produced from off-island sources were most often correlated with specialized-use house sites reserved for the social, ritual, and political elites, whereas there was less variation between elite and commoner residences used as sleeping structures. A recent Hawai 'i Island study by Rieth et al. (2013) documented significant variation in access to local versus exotic basalt and volcanic glass resources in late precontact chiefly occupations. The authors related this pattern to the specific activities carried out at the excavated elite contexts, while the creation and maintenance of social networks was identified as another potential factor. Functional variation between house sites is an avenue that requires additional exploration in future household archaeology studies in East Polynesia (see below). As a case in point, based on sourcing studies, precontact New Zealand house sites lack status-based differences in access to raw materials used for stone tool production or other activities. Yet there may be status-based differences related to the specific production activities carried out at house sites of differing types and size, as indicated by artifact frequencies and the identification of activity areas (Sutton 1990c).

Food choice is a daily practice that includes decisions about appropriate foods to be eaten, at what times, and by whom. It is related not only to shared values but to household labor allocations (Smith 2006). For the Hawaiian archipelago, there is strong evidence that consumption of foodstuffs can vary dramatically between elite and commoner households. High-status "fleshy foods" (pig, dog) are more commonly represented in elite contexts, as are choice cuts of pig, chicken, shark, and birds (Field et al. 2010; Kirch and O'Day 2003; O'Day 2002; Weisler and Kirch 1985). In contrast, commoner house sites in Kahikinui, Maui, lacked access to dog, had small, subprime cuts of pig, small littoral-sized fish, and frequent evidence for rat consumption (Kirch 2014; Kirch and O’Day 2003). A study of Kohala, Hawai 'i Island, illustrated that faunal consumption patterns are best examined broadly through time and space rather than strictly comparing elite versus commoner contexts. Field et al. (2011) demonstrated variation in faunal consumption patterns between inland and coastal Kohala house sites, which they related to changes in household economics and the degree of household integration into larger socioeconomic units.

Few household excavations in other East Polynesian archipelagos have explored diversity in faunal remains and their relationship to rank and status, either due to the small number of house sites excavated or the lack of bone preservation. Even so, 
Easter Island provides important contrastive examples where household wealth and status seem to have been expressed mainly through house form and architectural elaboration, house size, house location, and the number of cooking features, rather than in the accumulation of material goods (McCoy 1976, p. 203), similar to New Zealand studies. Finally, my (Kahn and Coil 2006) Society Island study highlights how even the most mundane domestic features - the posts used to fashion pole and thatch houses - vary between elite and commoner residences. The particular choice of woods used to construct house posts was a symbol of household status and identity, as well as a semipublic display of wealth and sanctity. Thus although a number of characteristics can be used to differentiate commoner and elite house sites, they differ according to local historical contingencies and perhaps according to the degree of regional sociopolitical organization. There does seem to be patterned variation in how the most complex East Polynesian chiefdoms expressed household wealth in domestic sites versus the less complex (open) chiefdoms.

\section{Gender and Identity}

Formalization of residential space can be expressed in varied ways and can be linked to site function, social status, and gender. Certainly, tapu restrictions requiring that men and women cook and eat foods separately and perform other activities separately led to the arrangement of multiple structures in East Polynesian residential complexes, each with varying function (i.e., sleeping houses, cooking sheds, craft activity areas, men's houses, etc.). Van Gilder and Kirch (Van Gilder 2001, 2005; Van Gilder and Kirch 1997; see also Kirch 2014) interpret the juxtaposition of adjacent hearths in several precontact Hawaiian houses as local adherence to gendered segregation in cooking practices in the Kahikinui region of Maui Island. While men and women appear to have eaten together in the hale noa (eating house), the side by side hearths and presence of isolated hearths in exterior cooking structures and men's houses (Kirch 2014, pp. 127-133) supports compliance with eating restrictions, even for Hawaiian commoners living in the hinterlands. Viewing such data through feminist practice theory, Van Gilder (2005) argued that gendered eating practices in late precontact Kahikinui were foci for heterodoxic practice. Dual earth ovens also have been recovered at domestic sites in Halawa Valley, O`ahu (Hendren 1975), which suggests patterned variation at the regional scale. On Easter Island, McCoy (1976, pp. 22, 50) maintained that multiple cooking ovens were a common occurrence in precontact residences of persons of rank (chiefs or priests) and reasoned that these patterns represent adherence to tapu rules. In the Society Islands, Oakes (1994) claimed that compartmentalized storage pits represent intentional separation of men's and women's foodstuffs. Similarly, my excavations at a Society Island cookshed associated with an elite sleeping house recovered a segmented breadfruit fermentation pit with two compartments separated by a stone lining (Kahn 2005, p. 230) that may represent adherence to tapu regulations. Thus current excavation data, while sparse, suggest the broad presence of gendered food preparation, storage, and consumption areas in precontact East Polynesia. 
While precontact household studies in Polynesia typically investigate gender through the structured use of space within sleeping houses and cooking areas, historic studies have applied a broad use of artifact analyses to identify women's activities and social roles, similar to analyses worldwide (Allison 2006, 2008; Beaudry-Corbett and McCafferty 2002; Keith 1998). In her analysis of the Te Puna Mission House in New Zealand, Middleton (2007, 2013) illustrated how artifact types found in the excavations signaled women's roles as teachers and reproducers of English society. Artifacts of "everyday domesticity," such as starched linens, irons for pressing lace, sewing gear (buttons, thimbles, pins), and ceramics with romantic, pastoral scenes of the British countryside, were used not only as efforts to reproduce home in this foreign place (see Naum 2012) but as civilizing elements fitting to the goals of the mission. At the same time, historic documents confirm how the civilizing efforts of the mission interfered with Maori social structure, which engendered acts of indigenous resistance (Middleton 2013).

Polynesian household archaeology that focuses on the historic period also has demonstrated how domestic spaces were nucleated after the abolishment of tapu rules. Separate buildings, formerly required to keep potentially profaning individuals or activities separate from sacred things or persons, were now integrated into multiroomed structures. In his Hawaiian study, Ladefoged (1991; Ladefoged et al. 1987) noted that historic residential clusters had contiguous activity areas, high enclosures, and large walls; the latter likely represent both the adoption of Western notions of land tenure and the need to protect the residence from historically introduced range animals (cattle, goats) (Kirch 2014). Kirch and Sahlins's (1992b) Anahulu study from Hawai'i documented that open exterior pavements (lanai) fronted historic period dwellings and were used as activity areas. They recorded how by the mid-1800s, changes in house form included attachment of a cookhouse to the primary dwelling (1992b, p. 74), an increase in walls surrounding the domestic areas, and an elaboration of the dwelling terrace (1992b, p. 176). They reasoned that these changes reflect the complete disintegration of the kapu system by the mid-19th century. In a few unique cases in the Society Islands and the Hawaiian Islands, religious converts or, conversely, anti-Western revitalization groups wishing to renew traditional religious ways modified ancient temple sites into habitation structures, perhaps the most pronounced inversion of the ancient tapu restrictions (Eddowes 2001; Kirch 2014, pp. 237-241). These latter studies share similarities with bottom-up models of collapse, which note how the appropriation of formerly elite sacred spaces can serve as forms of resistance, engagement, and independent action in postcontact societies (Janusek 2004; Joyce et al. 2001; Middleton 2012; Mixter et al. 2014; Schwarz 2013).

In a similar manner, historic household excavations have identified significant diversity in postcontact domestic sites associated with Polynesian cultures and those of Europeans. Mill's (2009) discussion of John Young's 1790-1800s homestead is a case in point. Young, a British boatswain who was left ashore in Hawai' $i$ and had to adapt to native Hawaiian culture, married two elite Hawaiian women and constructed his homestead with timber-framed thatched houses, some of which had lime plastering. While Young's sleeping house had lime plastering, that of his Hawaiian wife remained in the traditional grass thatch form, leaving Mills to 
propose that Young utilized lime plaster as a public display of his unique social status, albeit an identity that was negotiated vis à vis that of his Hawaiian wife. In contrast, Flexner's (2010) analysis of dispossessed, marginalized Hawaiians in the Hansen's disease settlement of Kalawao, Moloka ‘i, found continuity in 19th century house forms. Three styles were represented: the historic post on pier form, traditional rectangular foundations with pole and thatch superstructures, and standing stone masonry with an attached chimney. Flexner argued that the continuity of the traditional pole and thatch house allowed for Hawaiian Hansen's disease residents to reestablish a sense of home. The Hutchinson house, belonging to a superintendent, had a large enclosure and rich artifact assemblages, which signals the important status of the house residents and is reminiscent of status signaling in precontact house sites.

In his review of New Zealand historical archaeology, Smith (2004) lays out an agenda for situating household analyses more broadly within anthropological studies, particularly the study of the diversity of postcontact communities in New Zealand. While few Maori period historic houses have been excavated, European sites have been broadly sampled (missionary houses, forts, whaling stations, sealing gang camps, merchant houses, farmsteads, rural dwellings); considerably less attention has been paid to Chinese sites or those related to other minority groups (Adamson and Brader 2013; Ritchie 2003; Smith 2002, 2004).

\section{Specialized-Use House Sites and Occupational Specialization}

A surprising discovery has been the degree to which specialized activities were carried out at some precontact Polynesian house sites. Weisler and Kirch (1985) suggest specialized adze production is present in dwellings at Kawela, Moloka'i (see Fig. 3), and Taomia's (2000) research in the Cook Islands established that specialized adze production and wood working were found at a joint residential area/craft production locale. The presence of specialized activity areas within residential structures or locales of craft production adjacent to domestic areas have been advanced for the Hawaiian archipelago (Dixon et al. 1994; Weisler et al. 2006; Weisler and Kirch 1985), the Society Islands (Kahn 2005; Oakes 1994; Sinoto 1979), and other areas of the Cook Islands (Walter 1998). Identifying specialized-use house sites in the archaeological record requires detailed artifact analyses to delineate the organization of production, consumption, and use of tools at a range of house sites.

House sites that are the foci of specialized, nondomestic activities should differ from those used for mundane, daily activities in both the constellation of subsurface features and associated material culture. Taomia's excavations at MAN-95 in the Cook Islands recovered a high density of chert and basalt flakes associated with a paved area. The recovery of a cache of eight adzes, along with other artifacts such as sharks' teeth, led Taomia (2000, p. 151) to propose that the site served as the residence of a carver. In another Cook Islands study, Walter (1998) interpreted a residence as a dwelling of an adze-making specialist, based on identification of a residential structure with a formal pavement and a locus of intensive lithic reduction activities. In a Society Islands example, Oakes (1994, pp. 80, 94) argued that the high density of lithic artifacts recovered from within rectangular house 
structure 171A (see Fig. 4) indicates that it was a locus for stone tool production, adze reduction, and maintenance and that it served as an elite residence, perhaps for an adze specialist. During my later excavations at an upslope house (170), I (Kahn $2005,2007)$ identified an outdoor adze production area attached to that house (Fig. 4). I argued that 171A more closely resembled a specialized-use site rather than a sleeping house and that it likely functioned as a specialized indoor adze reduction area, ancillary to the 170 residence. It is likely that the same person or persons who completed adze reduction at the 170-WS workshop were the same as those who used the interior of 171A.

Another axes of variability relates to differences between houses used as domestic residences (sleeping houses) and those used as communal structures, including those to house visitors and ritual practitioners, those to store scars, and those serving as men's houses where men ate and carried out communal activities. In the Society Islands, the type and intensity of particular production and consumption activities are particularly important for identifying specialized-use houses (Kahn 2005; Kahn and Kirch 2013). At ScMo-120, a house interpreted as a specialized structure for storing, sculpting, and manufacturing ritual items, two flattopped boulders were located in the house interior, surrounded by high concentrations of polished flakes and debitage (Fig. 5; Kahn 2005, 2007). This house lacked the typical constellation of cooking and food storage features in areas exterior to the house, and wood charcoal assemblages from the house included sacred tree species known to be used in canoe manufacture and the sculpting of ritual wooden objects such as god figures (Kahn and Coil 2006). In a Hawaiian study, Dixon et al. (2008) investigated potential men's eating houses that, based on surface remains, were the largest and most elaborate structures within each

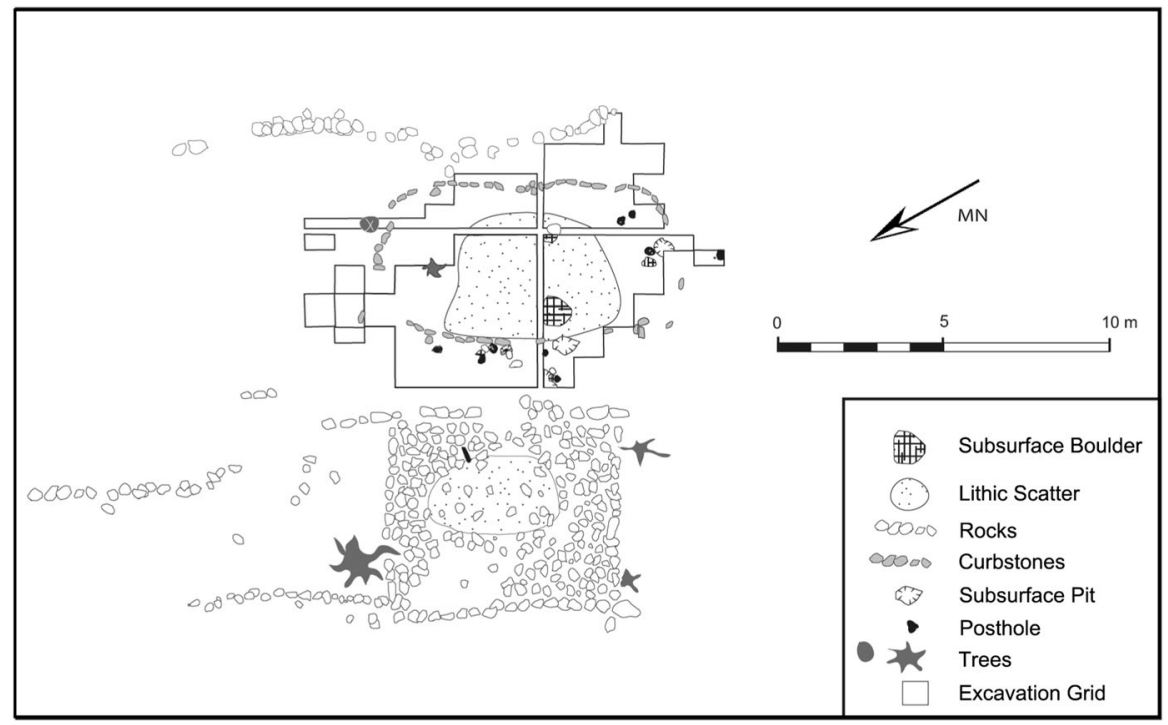

Fig. 5 Plan view of ScMo-120, 'Opunohu Valley, Mo'orea, Society Islands. Two interior boulders in the house were associated with small-sized lithic debris suggestive of adze use and sharpening 
residential group. Given kapu rules, men had to eat separately from women and were afforded the luxury of eating highly regarded sacred foodstuffs. The authors illustrate how many of the possible men's houses were situated in isolated residential clusters with empty spaces, described as "ritual[ly] dentrali[zed]" zones that created buffers between those of high status and low status, so that kapu restrictions could be easily followed. The excavated men's houses had strong evidence for ritual, male foodstuffs and stone tool production and use, supporting their specialized interpretation.

Clearly, identifying specialized-uses houses, residences of craft specialists, and communal-use dwellings is important for understanding diversity at the local scale linked to social status and occupational specialization. Some types of specialized house sites, such as meeting houses and warrior houses, provide important locales for community political engagement (see below). However, such functional interpretations of house structures require large horizontal excavations at multiple structures within a village or complex and close attention to architectural elaboration, use of space, subsurface features, and artifact patterning.

\section{Domestic Ritual}

There has been a small but growing interest in ritual and symbolism in East Polynesian household archaeology, similar to worldwide patterns (Carballo 2011; Pluckhahn 2010; Robin 2003). Weisler and Kirch (1985) first drew attention to the role of domestic ritual when they argued that elite and commoner house sites in Hawai' $i$ varied in the form and placement of ritual features, whether an upright stone was found within the domestic site or in an exterior and often larger or more formalized ritual enclosure. Current studies take a broader view of domestic ritual, focusing on three main forms: (1) symbolism, cosmology, and ancestor worship, (2) dedication ceremonies, and (3) feasting.

In Polynesia, a number of authors have explored cosmological and symbolic aspects of house layout, particularly through the analysis of ethnohistoric documents (Kahn 2005, 2007, 2014b; Kirch 2000; Prickett 1982; Sutton 1990a). These studies are founded on the belief that Polynesian ritual cannot be considered separate from other sociopolitical or economic spheres. Generalized dichotomies of sacred versus profane and ritual life versus daily life must be problematized, particularly since Polynesian residential sites can be the loci for the production and use of ritualized objects. A case in point is the recovery of ochre, used as body paint to signal one's mana and power, and ochre-manufacturing tools in precontact house sites in New Zealand (Furey 1996; Sutton 1990c). Furthermore, ethnohistoric documents illustrate that Polynesian houses are actively constructed as symbols of the ancestors and as living entities to which ritual offerings and incantations must be made (Kahn 2008; Kahn and Coil 2006).

In analyzing house architecture and the use of space, and particularly patterning in subsurface features, Polynesian archaeologists have relied heavily on ethnographic analogy, most notably, the direct historical approach. In a New Zealand study, Prickett (1982, pp. 114-115) utilized ethnohistoric evidence and archaeological data to argue that the traditional Maori house form was conservative and 
organized following important symbolic and behavioral parameters, such as the concepts of noa (profane) and tapu (sacred, restricted). His model of the Maori household includes a porch located in the east associated with craft activities, a small door typically on the right side of the house, a lack of food remains in the internal structure, and differential gendered use of space within the household, with male activities at the front, female activities at the rear (Prickett 1982, pp. 132-139). Prickett reasoned that the material correlates of the Maori house should provide insight into social organization and cultural meaning. Yet household excavations have uncovered more variability in the use of space and artifact distributions and their relationship to house structures (Sutton 1990a) than is present in Prickett's largely ethnographic model of the Maori house. Sutton argued (1990c, p. 201) that variation in site proxemics and architectural elaboration in kainga (undefended Maori house clusters) related to status differences. Sutton posited that the headman for the residential group lived in the most elevated house, while profane activities were carried out to the side of the house most removed from the front entrance. He claimed that headman houses were highly proscribed in form and structured with symbolic meaning; furthermore, they served as proto-marae, ancestral to community-level meeting spaces for public ritual (Sutton 1990c, d). Sutton's argument has been criticized by others as subjective and overly dependent on ethnographic analogy (Crosby 2004), paralleling larger debates about the role of analogy in archaeological interpretation in the Pacific and elsewhere (Alberti and Marshall 2009; Fowler 2004; Ravn 2011; Roscoe 2009; Spriggs 2008). Despite critiques, Sutton's analysis provides a rare example of a postprocessual structuralist analysis in Polynesian archaeology.

Other current investigations into the ritual nature of the Polynesian house draw from the "house society" literature. Lévi-Strauss (1979, pp. 45, 51) introduced the concept of the "house" as a social structure, or corporate body, holding a landed estate made up of material and immaterial wealth and perpetuated through the transmissions of rights, names, goods, or privileges. Ethnographers have documented the important role of houses in modern Austronesian-speaking cultures of Oceania (including East Polynesia) and island Southeast Asia (Carsten and HughJones 1995; Fox 1993; Macdonald 1987; McKinnon 1991, 1995; Reuter 2002; Waterson 1990). They have illustrated that dwellings and the daily activities carried out in or around them, such as food preparation, food sharing, feasting, and gift exchange, have ritual and symbolic meaning. A common characteristic of house societies of Austronesia (of which Polynesia is a part) is that features of buildings serve symbolic rather than purely functional purposes; the material construction and layout of the physical house articulate the dwelling with symbolism and ritual meaning (Kirch 1996; Waterson 1990, p. 91). Architectonic features of the dwelling, including architectural elaboration and spatial layout of house structures within the community, often represent facets of social differentiation linked to hierarchical rank, social status, and wealth and gender difference (Fox 1995; McKinnon 1991; 2000; Parmentier 1987; Reuter 2002; Waterson 1990; see also Firth 1957).

Recently, archaeologists have investigated the ritualization of Polynesian domestic architecture and how particular features signal close association with 
the ancestors. Society Island studies illustrate how upright stones and house posts served as "ritual attractors," symbolizing close ties to the ancestors and status relations (Kahn 2007; Kahn and Kirch 2013; see also Kirch and Green 2001, p. 254). Varied forms of decorative treatment drew attention to Society Island house posts (polishing, carving, dyeing, wrapping in cordage or barkcloth, or their large size), as described in early European voyager accounts (Beaglehole 1962(I), p. 364; Morrison 1935). Archaeological data from the Societies and elsewhere in East Polynesia document evidence for post-emplacement ceremonies, including claylined pits surrounding the post and offerings left at their bases (Kahn 2008). These studies highlight how close attention to patterning in subsurface features and artifacts is needed to develop social interpretations of domestic structures in East Polynesia.

Other researchers highlight the importance of architectonic features in investigations of Polynesian domestic ritual. In an Easter Island study, Hamilton (2013) applied a phenomenological approach and artifact life-history perspective to argue that the reuse of house curbstones at elite dwellings symbolized links between ancestral houses and "lineages of stone." In the Hawaiian Islands, archaeological data from precontact domestic contexts suggest a preference for ritual spaces with a north, northeastern, or eastern orientation (Kahn 2014b). In Hawaiian ontologies, east was associated with the gods, sacredness, and kapu (see Valeri 1985). Areas used in Hawaiian domestic ritual were materially marked by niches within the house, sometimes with offerings such as water-worn stones (Van Gilder 2005, p. 209), or shrines with upright stones representing the household gods, often found in association with coral heads or branch coral offerings (Field et al. 2010; Weisler and Kirch 1985; Weisler et al. 2006). While it has been difficult to locate direct material remains of domestic ritual in the Polynesian archaeological record, I suggest that closer analysis of house features and the sediments around them might be a fruitful avenue, as ethnohistoric accounts indicate that libations and offerings were left around ritual features during domestic rites. In this way, familiar practices, such as cleaning out domestic fire pits and dumping their remains on the central house post, or replacing and emplacing new house posts, can be imbued with ritual meaning.

East Polynesia ethnohistory documents significant evidence for the widespread presence of house dedication or opening ceremonies (Bayman and Dye 2013; Kahn 2008, 2014b), yet it may be difficult to find traces of such ritual activities in the archaeological record. In Hawai' $i$, house-opening ceremonies, termed "cutting the umbilical cord of the house," involved clipping a tuft of grass positioned over the front door of the house (Brigham 1906, p. 287; Malo 1951, pp. 121, 124-125), underlying the ritual nature of the house and its embodiment as an animate, living entity with its own life force (Handy 1923, pp. 150-152). This is similar to practices recorded for the Marquesas Islands, where newly constructed houses were ritually "opened" with recitation of origin myths asking ancestral gods to contribute to the well-being of the house (Handy 1923, pp. 151-152). Excavations at a historic house site on Kaua' $i$ in the Hawaiian Islands revealed that deliberate offerings were placed in the house architecture, either during its construction or during an opening ceremony (Kahn 2014b). These included the internment of a juvenile pig in a pit 
under the northeast corner of the house terrace, underneath the large foundational facing stones. While few traces of domestic house-opening ceremonies have been recovered, as microscale analysis of Polynesian house sites continues, such remains can be expected to be found with higher frequency.

While worldwide studies reflect an increased interest in domestic feasting (Brown 2001; Earle and Smith 2011; Gumerman 2010; Junker 2001; Nash 2009; Robin 2003; Vaughn 2004), this theme has received little attention in Polynesia, despite ample ethnohistoric evidence that feasting was a common event at the microscale and took place in both residential and ritual contexts. For example, emic accounts, notably Tahitian lexical data, document how pua'ata'ipito, pua'atafeti 'i, pua'afatoi were secular feasts "for family and relations only" (Davies 1851, p. 205; Kahn 2005, 2007). As Kirch (2001) noted, domestic feasting in Polynesia was often related to rites de passage, such as puberty rites and marriage ceremonies. Kirch further argued that Hawaiian elites carried out frequent feasting, both in domestic and ceremonial (monumental temple) contexts. Yet there is little evidence that Hawaiian commoners feasted within domestic sites, suggesting status variation in the frequency of precontact Polynesian feasting.

Material evidence for household feasting remains scant in East Polynesia. Within the ScMo-170/171 complex (Fig. 4), excavations at house site 171A recovered evidence for two large earth ovens and a series of pits for fermenting breadfruit on flats exterior to the house (Oakes 1994). The size of the earth ovens and density of storage pits are suggestive of stockpiling for feasting (see Leach 2010). In later excavations at other structures in the same complex, I (Kahn 2005, 2007) uncovered potential evidence for communal feasting and household ritual on terraces 171D and $171 \mathrm{E}$. These activity areas were situated adjacent to a simple temple, 171F, which is interpreted as a family-level temple. At least in the Society Islands, the size, location, and type of cooking facility (e.g., large earth ovens) are potential signifiers of feasting activities. While one might expect that elite households would perhaps most frequently practice communal feasting as a means for broadcasting their largess and economic prowess, it is likely that commoner households also feasted. Historic accounts note that lower-ranking Tahitians had to pool their breadfruit harvests to feast and describe how neighbors and families joined in making communal breadfruit ovens (Morrison 1935, p. 214). Ethnohistoric records throughout Polynesia describe how the construction of large earth ovens for cooking the $t \bar{l}$ plant (Cordyline fruticosa) were communal endeavors (Carson 2002), likely requiring multihousehold labor, while Carson's synthesis of the archaeological data suggests that $t \bar{l}$ cooking earth ovens tend to be associated with elite residences (Carson 2002; see Davidson 1974b; Holmer 1980). Recovering feasting activities within residential complexes in Polynesia requires broad-scale excavations of areas exterior to a range of houses of varying elaboration, including terraces adjacent to house sites that lack traces of domestic architecture. Such types of excavations should be prioritized in future studies to enrich our understanding of the role of domestic ritual and feasting at the microscale. 


\section{Articulation with the Community and Change Through Time}

To study how households articulate with communities, researchers call for complex modeling and tacking forth between diverse types of data and multiple scales of evidence (Frankel and Webb 2006; Guerrero et al. 2009; Peterson and Shelach 2012; Rodning 2009). East Polynesia archaeologists follow such tenets, focusing on diachronic shifts in house form, household organization, and domestic economies. At Moikau (New Zealand), Leach and Leach (1979) argued that, although there was little change in house form through time, households became more formally independent economic units. In the rest of East Polynesia, archaeological and ethnohistoric studies illustrate how households are the basic unit of production at the mesoscale of the community (Kahn 2005; Kirch and Sahlins 1992a; Walter 2004, 1996), providing a bridge between the micro- and macroscales.

Through a focus on household size and domestic production, Field and colleagues have provided innovative analyses situating Hawaiian households within larger communities. Their Kohala study (Field et al. 2010) demonstrated diachronic shifts in household size and economic integration. Large houses with robust architecture developed on the coast in the final period (AD 1650-1800). Those with relatively short chronologies and large marine midden assemblages were interpreted as localized nodes in the microscale economy, providing surplus goods and labor to chiefs and administrators. These surplus-producing households developed out of an earlier context where small residences with only moderate foodstuffs practiced more independent forms of domestic production. In an innovative analysis, Field et al. (2011) utilized their Kohala data to demonstrate how shifts in household composition and domestic economy developed in parallel with the establishment of sociopolitical territories, land divisions within them, and agricultural production. Utilizing field alignments and trail abutments, the authors developed a relative chronology of house construction, arguing that the earliest phase of inland settlement was by small household units in a field system that had little connection to coastal settlements. After AD 1520, large portions of the inland Kohala agricultural field system were established and household economies shifted. The number of inland and coastal residences increased, and there was greater integration of the inland and coastal economies, perhaps spurred by household fissioning and population growth. While the quite small excavation areas (as little as $.5 \mathrm{~m}$ within a structure) might leave some to label their studies as "house based" rather than household archaeology, the large sample size of excavated houses that this methodology afforded certainly facilitated broad-scale comparisons at the community level.

Other Polynesian archaeologists focus on diachronic changes in household social status in an effort to link shifts in sociopolitical complexity at the microscale to community and regional processes. Walter (2004) reasons that in many early Archaic period (c. AD 900-1100, my estimate for the Archaic age range) Polynesian villages there is no unequivocal evidence for elaborate domestic architecture. This contrasts with the domestic architecture found in later residential sites (typically post-AD 1350 but sometimes centuries later), where houses and auxiliary structures were enlarged and built with more elaborate architectural styles, 
signaling the advent of ritualized house architecture and status differentiation (Allen 2009; Field et al. 2010; Green 1996; Kahn 2014a; Kahn and Kirch 2013). While few researchers have investigated household status from early settlement or Archaic period sites, the inclusion of goods in burials and the layout of residential sites suggest that central East Polynesian societies (Australs, Cooks, Marquesas, Societies, Tuamotus) were organized as loosely ranked chieftainships or heterarchical societies (Lepofsky and Kahn 2011). This interpretation, however, is based on a slim amount of archaeological evidence and linguistic reconstructions (Kahn 2014a) and should be tested with additional studies at the microscale. Certainly, more broad-scale excavations at Settlement and Archaic period sites are required to reveal the spatial layout and elaboration of residential sites as well as ritual contexts. These data will be instrumental in testing theories about the emergence of social complexity and the development of status differentiation and ideology in East Polynesia chiefdoms.

Current data allow for regional comparisons to be made for households in the latter parts of the chronological sequence. In at least the Hawaiian Islands and the Society Islands, status differentiation in residential groups is expressed most forcefully after significant shifts in the subsistence base occurred several centuries after initial settlement (Kahn 2014b). For example, utilizing a house society perspective and a landscape approach, Kahn and Kirch (2013) argued that elite residential sites and temples were constructed early in the settlement of the Amehiti district of the 'Opunohu Valley c. AD 1350. Such practices validated the group's corporate rights to the landed estate and established access to important resources, including nutrient-rich agricultural lands, permanent streams, and springs. This suggests that the often-rapid movement into the interior valley for establishing permanent settlements may signal a "full land" situation on the coast or population and resource pressures (Hamilton and Kahn 2007; Kahn 2011). Residential sites of moderate to low status are found later on the Amehiti landscape and are situated on less productive agricultural lands, signaling that status distinctions affected both the microscale and broader community landscapes. In contrast, late elite residential complexes in Kohala, Hawai'i Island, highlight that Hawaiian elites did not have to emphasize their long-term connections to the landed estate and the ancestors in the same way that elites had to in the Society Islands, at least not at the local scale. In coastal Kohala, I have argued that late precontact high-status households imply the imposition of an elite presence, perhaps that of lesser chiefs or land managers on the local landscape (Kahn 2014b). These individuals' claims to power rested in their political relationships to the high chiefs (or divine kings) rather than in organic social relations. In this way, we see how a focus on households provides insight not just into economic relations but into shifts in sociopolitical organization at both the inter- and intra-archipelago scales.

Other glimpses into sociopolitical transformations are provided by a focus on specialized house sites associated with socioritual elites and persons of high status. Such houses are constructed late in regional chronological sequences in East Polynesia, often near elaborate temple sites or elite residential complexes. Linguistic reconstructions and ethnohistoric data reveal that specialized communal houses in Polynesia could include public meeting houses for assemblies and 
entertainment, houses for guests, houses for storing ritual objects, and houses for members of fertility cults (Buck 1930; Green 1986; Handy 1932; Jonassen 1994; Orliac 2000. Walter 1996). Other types of specialized structures include men's houses (Dixon et al. 2008; Van Gilder 2005, pp. 227, 240-241, 243) and priests' houses (Kahn 2015).

Archaeological and ethnohistoric data indicate that communal houses sometimes resemble elite residences with respect to architectural elaboration or site proxemics but differ in their constellation of activity areas and subsurface features (Kahn 2005; Orliac 1982). In the Society Islands, I have argued that the construction of specialized community houses, such as fare ia manaha for storing sacred items and fare 'arioi for housing visiting members of the fertility/war cult, were material expressions of social difference within neighborhoods and communities (Kahn 2005 , 2007). Specialized houses, used only by a select few high-ranking members of the community for activities often of a ritualized or political nature, effectively created landscapes that legitimated hierarchical roles. In much the same way, priests' houses, which have been identified in the Societies and the Hawaiian archipelago after AD 1500 (Kahn 2005; Kirch et al. 2010), served as markers of specialized status and access to ritualized activities (Kahn 2015). Furthermore, I claim that similarities between late precontact elite residences and specialized-use house sites of ritual function (whether for storing sacra or for housing priests) are the result of intentional actions, due to the needs for materializing sacred places.

Another regional pattern deserving attention is the advent of fortified sites and their associated house terraces and storage pits. In New Zealand, fortified sites ( $p a$ ) developed c. AD 1500 in defendable positions with ditches and banks (Walter et al. 2006). They vary in their constellation, sometimes having permanent house sites, sometimes having little evidence for dwellings, but always they are associated with pit storage and cooking activities (Sutton et al. 2003). Hilltop fortified sites on the island of Rapa (Austral Islands) developed as early as AD 1300-1400, but their density on the landscape proliferated rapidly after AD 1700. Survey and excavations have documented that these sites functioned as fortified residences or villages. Hilltop sites include residential platforms with evidence for cooking and storage activities (earth ovens, oven rake out, storage pits, possible water cisterns) and domestic midden resulting from daily activities (rat and fishbone, adze flakes, etc.) (Mulloy 1965; see also Anderson and Kennett 2012). The uppermost tower terraces may have served as chiefly residences and were associated with turtle bone, considered a chiefly foodstuff. The late increase in fortified village sites in Rapa signals rising population levels and increased intergroup competition over access to agricultural lands and other resources, as well as frequently violent encounters that necessitated the use of refuge areas and fortified residential sites (Anderson and Kennett 2012).

Finally, postcontact studies such as that by Holdaway and Wallace (2013) report on significant transformations in indigenous socioeconomic organization and shifts in relationships between land and people in colonial contexts. The mid-19th century Te Oropuriri, Taranaki (New Zealand) settlement consisted of a traditional Maori village with nucleated houses defended by a palisade. These were transformed into a gunfighter $p a$ (fortified site) in response to European land purchases and subsequent 
conflicts. In the late $1850 \mathrm{~s}$, the settlement was transformed again into a dispersed settlement with a communal meeting house defended by palisades and gunfighter trenches. The study documents ever-shifting postcontact politics of land tenure from a dynamic perspective, similar to other New Zealand colonial period research that focuses on the consequences of European settlement for indigenous Maori and, in turn, aspects of Maori agency (Allen and Phillips 2013; Phillips 2000).

\section{Conclusions}

Because of the relative infancy of household archaeology in Polynesia, there are few comparative data sets available for most archipelagoes outside of Hawai'i, New Zealand, and the Society Islands. Few domestic structures have been excavated in detail, and most studies, because of time and budget constraints or limitations of research design, have excavated a single house structure or only a few structures within a few residential complexes. Thus, while in some archipelagoes the range of residential site types has been established, the social implications of this variation are not yet well understood. It is clear, however, that diverse lines of evidence must be used to interpret aspects of social variability at the microscale in Polynesia.

The more successful projects in East Polynesia have provided holistic interpretations of household diversity, utilizing house architecture and its associated material remains (artifact distributions, subsurface features, and other microtraces of domestic activities). Projects that have explicitly investigated socioeconomic variation among prehistoric households through excavations of a range of house types have established that household variation can take many forms and is linked to a series of social factors. There are hints that in some contexts, specialized craft production took place in specialized-use house sites that may have been linked to socioritual elites, while in other contexts local-scale craft production may have been attached to the houses of the headman who served as leaders for extended residential groups. Further analysis of such patterns will illustrate whether East Polynesian elites distinguished themselves by occupation, either as artisans or ritual practitioners, as a means of differentiating themselves from other social classes, as has been found in other complex societies (Inomata 2001; Knight 2004). Another clear pattern in East Polynesian household archaeology is that there is greater diversity than expected from ethnohistoric models, similar to worldwide patterns (Allison 2001; Carballo 2011; Carpenter et al. 2012; De Lucia and Overholtzer 2014; Guengerich 2014; Levine 2011; Nash 2009; Pluckhahn 2010; Robin 2003). This is likely associated with a number of factors, including the normative and idealized nature of the historic accounts. Further research must address the degree to which variance in traditional Polynesian households may be related to adaptation to differing ecological environments, duration and intensity of site use, differential household wealth or status, site function and specialization in activities, regional intra-archipelago traditions, and gendered relations. Current studies hint at differing degrees of status elaboration of residential architecture between open and complex East Polynesian chiefdoms. Additional comparative studies of this nature may illuminate cultural processes underlying macroscale patterns of increasing social 
complexity in the region. Another fruitful avenue is investigating the role of gender in the development of status roles, social complexity, and the organization of household labor. This topic has been little explored in Polynesia, in large part, because many artifacts expected to have gendered connotations, such as the tools used to make barkcloth, preserve poorly in tropical Polynesia. This could be an area where microfossil analyses may prove successful, at least for delimiting potential gendered activity areas in precontact households (see Kahn et al. 2014).

Like other regions (American Southwest, South America, Mesoamerica) with living descendant communities and relatively rich ethnographic and ethnohistoric data, household archaeologists in East Polynesia often utilize ethnographic analogy, in particular the direct historical approach, to model potential axes of variation in late prehistoric residential sites. Polynesian archaeologists do so in order to reap the benefits of the direct historical approach and more general applications of ethnographic analogy, namely, the ability to produce a dynamic, peopled past, with reference to social actors and intentions and narratives of cultural change (Lepofsky 2009; Lyman and O'Brien 2001; Marcus and Flannery 1994; McNiven 2014; McNiven et al. 2010). Some of the potential problems of using the direct historical approach are mitigated in East Polynesia, given that we are dealing with island populations who appear to have had little regional contact and exchange in the last 600 years of their precontact sequence. Thus population continuity can be assumed in the precontact period (Lyman and O'Brien 2001), yet significant population losses were a factor in many regions in the postcontact period (Kirch and Rallu 2007). Even so, other pitfalls remain. Transformations of material culture and human demography may vary in pace and scale (Dunnell 1991; Lyman and O'Brien 2001; Spriggs 2008) in the postcontact period, leaving some postcontact house sites perhaps to differ widely in their construction and use than earlier structures. This theme has been taken up by Bayman (2009) in Hawai'i, but certainly problematizing the notion of cultural continuity and being aware of breaks due to culture contact are themes that could be explored at the microscale in other parts of East Polynesia.

Currently, most Polynesian household archaeologists actively practice source criticism (Lightfoot 1995; Stahl 1994), comparing and contrasting not only different ethnohistoric and ethnographic accounts but other independent lines of evidence (linguistic data, archaeological data) to create balanced interpretations of precontact residential sites and social practices, thus following current debates and practices of the direct historical approach and ethnographic analogy worldwide (Feinman 1997; Robin 2006). As this review illustrates, many Polynesian household archaeologists utilize ethnographic and ethnohistoric data to build models that can be tested with archaeological data, with fine attention to both similarities and differences between the two in efforts to describe social change, again following agreed upon practices of the direct historical approach and more generalized ethnographic analogy (Brumfiel and Robin 2008; Gould 1980; Marcus and Flannery 1994; Ravn 2011; Roscoe 2009; Stahl 1994; Webster 2008). But the question remains: how far back in the East Polynesian sequence can the direct historical approach be used by household archaeologists? Is it relevant to only the last 150 years, say post AD 1600 , or to the last few hundred years, say post AD 1400? Certainly Polynesian 
archaeologists recognize that early precontact ceremonial sites share little in form (and perhaps function) with the size, layout, and elaboration of later ritual structures. Similar patterns may hold true for early precontact house sites versus late precontact house sites in the region.

Expecting to find divergence between ethnohistoric/ethnographic models and the form, size, and function of specific types of house structures in East Polynesia is necessary to develop dynamic views of residential house sites and their use through time. Such a perspective is key to crafting interpretations of daily life at the local scale that historicize social relations rather than project status relations or gender relations as they existed in contact period households into the deeper past (Brumfiel and Robin 2008; Morehart and Helmke 2008; see also Verhoeven 2009). Diachronic perspectives outlining change through time in residential sites throughout the 1,000year East Polynesia cultural sequence are needed to address these questions. This is not an easy task, as certain archipelagoes, such as the Society Islands, have seen remarkable geomorphological changes along their coastal plains, including island subsidence that has resulted in contexts where older precontact residential sites are buried by 2-3 $\mathrm{m}$ of colluvium or are under the current water table (Kahn et al. 2015a, b). A similar pattern holds true for interior valley and coastal contexts in the Marquesas Islands, where flooding, sediment discharge, and tsunamis have buried archaeological complexes with substantial alluvial and colluvial deposits (see Allen 2009; Allen and McAlister 2010). Identifying early precontact house sites in some parts of central East Polynesia will be a daunting task, requiring detailed transects with bucket augering or shovel test pits. Site recovery may be facilitated by the use of geophysical techniques such as ground penetrating radar or magnetometry as their use is refined in the region.

Currently, there is a greater recognition that household archaeologists in Polynesia cannot trust surface architecture alone to make pronouncements of site function or social status, even though site proxemics commonly give insight into status and rank relationships in many parts of the region. The study of household rank and status is problematized by the fact that sleeping houses of the elites can mimic specialized-use houses used for craft production, ritualized production, and community-level activities. In such cases, horizontal excavations are required to outline subsurface features and artifact distributions, which can be used to model the use of space and intensity of daily activities. Kirch (2010) has proposed that Hawaiian elites lived in palaces similar to residences of elite leaders in archaic states. However, Hommon (2013) has noted that this hypothesis is largely based on surface residential architecture and limited artifact assemblages and requires testing with larger-scale excavation.

The importance of site proxemics for establishing household rank and status in Polynesia provides an emic perspective illustrating that houses were much more than containers for activities; rather, they were embedded within larger landscapes and social relations. It also brings to the fore differing notions of spatial relations, notably Pacific Islander "point-field" and "relational" perspectives (centerperiphery, windward-leeward, seaward-landward) versus Western "container" models (Campbell 2006; Lehman and Herdrich 2002, Palmer 2002; Quintus and Clark 2012; Shore 1996). Clearly Polynesian landscapes, and the house sites within 
them, were parts of larger ritualized landscapes of hierarchal relations, where both domestic sites and larger ceremonial complexes were distinctly situated and geographically distinguished. In this way, Polynesian proxemic perspectives share much with current debates on worldviews and ontologies (Alberti et al. 2011; Harris and Robb 2012) in addition to native landscape philosophies (Fowles 2010; Lekson 1999).

Certainly there are research themes that deserve more focus; one is the notion of gradations among rank and status within the elite class and within the lower status and commoner classes. Kirch (2010) and others (Dixon et al. 2008; Field et al. 2010; Weisler and Kirch 1985) have proposed that in Hawai' $i$ both district centers and communities had resident chiefs and land managers whose houses were large and architecturally elaborate, situated in high promontories near important natural resources or near temple sites, and associated with craft specialization. Such nuanced interpretations of rank and status at the microscale cannot be made in other archipelagos (excepting New Zealand), as the current sample size of excavated house sites is insufficient. Particularly problematic is the lack of excavated commoner house sites. As in other parts of the world, Polynesian archaeologists for the most part have focused on the larger and more elaborate house sites, while those of the everyday commoners have been generally overlooked. As household studies in other complex societies have shown, excavating commoner house sites is critical to understanding commoner agency and social transformations (De Lucia 2013; Feinman and Nicholas 2012; Joyce et al. 2001; Lohse and Valdez 2004; Robin 2013). Commoner households provided an important and dynamic economic basis for many social, political, and ideological transformations (Hutson and Welch 2014; Robin and Brumfiel 2008), which themselves engendered further adjustments at multiple scales (Earle and Smith 2011), themes that have only been tangentially been explored in East Polynesia (Dye 2010; Lepofsky and Kahn 2011).

In a similar manner, East Polynesia household studies would benefit from excavations of house sites in a range of sociopolitical landscapes, including those in central or core political areas, those in minor political centers, and those in the more marginal hinterlands. While some studies exist for New Zealand and Hawai ' $\mathrm{i}$, most archipelagos within central East Polynesia have only one or two household studies, often focused on the more central, politically important regions. Studies worldwide have shown that sociopolitical dynamics in hinterlands and areas outside central sociopolitical cores can inform greatly on regional patterns, particularly in testing notions of elite surplus extraction and control, and the extent to which political leaders' power had regional "reach" (Buell 2014; Emerson 2012; Herrmann 2011; Hirth 2013; Ossa 2013; Robin 2012). As such, investigating Polynesian commoner households in "rural" or hinterland locations far from political centers should shed light on variability in domestic economies, what Brumfiel and Nichols (2009) term "commodity chains and material flows." Future comparative studies in East Polynesia along these lines would be of great benefit and would allow regional household studies to play a role in contemporary debates on patterned variation, the development of social complexity, and the advent of inequality (Drennan et al. 2012; Drennan and Peterson 2006, 2011; Ur 2014; Wright 2014). 
Despite certain challenges and the need to broaden its research themes, the future of household archaeology in Polynesia seems optimistic. Household archaeology in Polynesia utilizes diverse theoretical perspectives and permits innovative analyses engaged with both the material and the nonmaterial aspects of the house. Households will continue to be a sustained unit of analysis in the region for decades to come, and such studies will have much to contribute to the analysis of social complexity in Polynesian chiefdoms.

Acknowledgments A household archaeology seminar led some years ago by Rosemary Joyce was quite influential on my initial thoughts into households and their study at the microscale. Since then, my thinking on Polynesian and Pacific Island households has benefitted from discussions with Roger Green, Patrick Kirch, and Christophe Sand. Melinda Allen and Thegn Ladefoged turned my attention to several unpublished theses and dissertations. I thank the journal editors and the helpful comments and suggestions of Thomas Pluckhahn and four anonymous reviewers. Ally Campo and Mallory Moran are thanked for redrafting the figures.

\section{References Cited}

Adamson, J., and Brader, H.-D. (2013). Gardening to prosperity: The history of archaeology of Chan Dah Chee and the Chinese market garden at Carlaw Park, Auckland. In Campbell, M., Holdaway, S., and Macready, S. (eds), Finding Our Recent past: Historical Archaeology in New Zealand, Monograph 29, New Zealand Archaeological Association, Auckland, pp. 143-165.

Alberti, B., Fowles, S., Holbraad, M., Marshall, Y., and Witmore, C. (2011). Worlds otherwise. Current Anthropology 52: 896-912.

Alberti, B., and Marshall, Y. (2009). Animating archaeology: Local theories and conceptually open-ended methodologies. Cambridge Archaeological Journal 19: 344-356.

Allen, H., and Phillips, C. (2013). Maori agency in colonial Hauraki: The historical archaeology of Ōpita. In Campbell, M., Holdaway, S., and Macready, S. (eds.), Finding Our Recent Past: Historical Archaeology in New Zealand, Monograph No. 29, New Zealand Archaeological Association, Auckland, pp. 97-122.

Allen, M. S. (2009). Oscillating climate and socio-political process: The case of the Marquesan Chiefdom, Polynesia. Antiquity 84: 86-102.

Allen, M. S. (2010). Morphological variability and temporal patterning in Marquesan domestic architecture: Anaho Valley in regional context. Asian Perspectives 48: 342-382.

Allen, M. S., and McAlister, A. J. (2010). The Hakaea Beach site, Marquesan colonisation, and models of East Polynesian settlement. Archaeology in Oceania 45: 54-65.

Allen, M. S., and Ussher, E. (2013). Starch analysis reveals prehistoric plant translocations and shell tool use. Marquesas Islands, Polynesia. Journal of Archaeological Science 40: 2799-2812.

Allison, P. M. (ed.) (1999a). The Archaeology of Household Activities, Routledge, London.

Allison, P. M. (1999b). Introduction. In Allison, P. M. (ed.), The Archaeology of Household Activities, Routledge, London, pp. 1-18.

Allison, P. M. (2001). Using the material and written sources: Turn of the millennium approaches to Roman domestic space. American Journal of Archaeology 105: 181-208.

Allison, P. M. (2004). Pompeian Households: An Analysis of Material Culture, Cotsen Institute of Archaeology, Los Angeles.

Allison, P. M. (2006). Mapping for gender: Interpreting artefact distribution inside 1st-and 2nd-century AD forts in Roman Germany. Archaeological Dialogues 13: 1-20.

Allison, P. (2008). Measuring women's influence on Roman military life: Using GIS on published excavation reports from the German frontier. Internet Archaeology 24. DOI: 10.11141/ia.24.5.

Ames, K. M. (1995). Chiefly power and household production on the Northwest Coast. In Price, T. D., and Feinman, G. M. (eds.), Foundations of Social Inequality, Plenum Press, New York, pp. $155-187$.

Anderson, A., and R. Green (2001). Domestic and religious structures in the Emily Bay settlement site, Norfolk Island. In Anderson, A., and White, P. (eds.), The Prehistoric Archaeology of Norfolk 
Island, Southwest Pacific, Records of the Australian Museum, Supplement 27, Australian Museum, Sydney, pp. 43-52.

Anderson, A., and Kennett, D. J. (eds.) (2012). Taking the High ground: The Archaeology of Rapa, a Fortified Island in Remote East Polynesia, Terra Australis 37, Australia National University EPress, Canberra.

Anderson, P.-K. (2001). Houses of the Kama'aina: Historical Anthropology in a Rural Hawaiian Valley, Ph.D. dissertation, Department of Anthropology, University of California, Berkeley.

Ashmore, W., and Wilk, R. (1988). House and household in the Mesoamerican past: An introduction. In Wilk, R., and Ashmore, W. (eds.), Household and Community in the Mesoamerican Past, University of New Mexico Press, Albuquerque, pp. 1-28.

Banning, E. B., and Byrd, B. F. (1989). Renovations and the changing residential unit at 'Ain Ghazal, Jordan. In MacEachern, S., Archer, D. J., and Garvin, R. D. (eds.), Households and Communities: Proceedings of the Twenty-first Annual Conference of the Archaeological Association of the University of Calgary, University of Calgary, Calgary, pp. 525-533.

Bayman, J. M. (2009). Technological change and the archaeology of emergent colonialism in the Kingdom of Hawai 'i. International Journal of Historical Archaeology 13: 127-157.

Bayman, J. M., and Dye, T. S. (2013). Hawai ' $i$ 's Past in a World of Pacific Islands, Society for American Archaeology Press, Washington, DC.

Beaglehole, J. C. (ed.) (1962). The Endeavour Journal of Joseph Banks 1768-1771, 2 volumes, Angus and Robertson, Sydney.

Beaudry, M. (1989). Household structure and the archaeological record: Examples from the New World historical sites. In MacEachern, S., Archer, D. J., and Garvin, R.D. (eds.), Households and Communities: Proceedings of the Twenty-first Annual Conference of the Archaeological Association of the University of Calgary, University of Calgary, Calgary, pp. 84-92.

Beaudry-Corbett, M., and McCafferty, S. (2002). Spindle whorls: Household specialization at Ceren. In Ardren, T. (ed.), Ancient Maya Women, AltaMira Press, Walnut Creek, CA, pp. 52-67.

Beliaev, D. D., Bondarenko, D. M., and Korotayev, A.V. (2001). Origins and evolution of Chiefdoms. Reviews in Anthropology 30: 373-395.

Bellwood, P. S. (1972). A Settlement Pattern Survey, Hanatekua Valley, Hiva Oa, Marquesas Islands, Pacific Anthropological Records 17, Department of Anthropology, Bernice P. Bishop Museum, Honolulu.

Bellwood, P. S. (1978). Archaeological Research in the Cook Islands, Pacific Anthropological Records 27, Department of Anthropology, Bernice P. Bishop Museum, Honolulu.

Best, E. (1924). The Maori as He Was: A Brief Account of Maori Life as it was in Pre-European Days, New Zealand Board of Science and Art Manual No. 4, Dominion Museum, Wellington.

Blanton, R. (1995). The cultural foundations of inequality in households. In Price, D. T., and Feinman, G. M. (eds.), Foundations of Social Inequality, Plenum Press, New York, pp. 105-128.

Brigham, W. T. (1906). Mat and Basket Weaving of the Ancient Hawaiians: Described and Compared with the Basketry of the Other Pacific Islanders, Memoirs of the Bernice Pauahi Bishop Museum Vol. 2, No. 1, Bishop Museum Press, Honolulu.

Brown, L. A. (2001). Feasting on the periphery: The production of ritual feasting and village festivals at the Ceren site, El Salvador. In Dietler, M., and Hayden, B. (eds.), Feasts: Archaeological and Ethnographic Perspectives on Food, Politics, and Power, Smithsonian Institution Press, Washington, DC, pp. 368-390.

Brumfiel, E., and Nichols, D. (2009). Bitumen, blades, and beads: Prehispanic craft production and the domestic economy. In Hirth, H. G. (ed.), Housework: Craft Production and Domestic Economy in Ancient Mesoamerica, Archeological Papers No. 19, American Anthropological Association, Wiley, Hoboken, NJ, pp. 239-251.

Brumfiel, E., and Robin, C. (2008). Gender, households, and society: An introduction. In Robin, C., and Brumfiel, E. (eds.), Gender, Households, and Society: Unraveling the Threads of the Past and the Present, Archeological Papers No. 18, American Anthropological Association, Blackwell, Malden, MA, pp. 1-16.

Buck, P. H. (Hiroa, T. R.) (1930). Samoan Material Culture, Bernice P. Bishop Museum Bulletin 75, Bishop Museum Press, Honolulu.

Buell, D. M. (2014). The rise of a Minoan city and the (re) structuring of its hinterlands: A view from Galatas. In Creekmore, A. T. III, and Fisher, K. D. (eds.), Making Ancient Cities: Space and Place in Early Urban Societies, Cambridge University Press, Cambridge, pp. 257-291. 
Byrd, B. F. (1994). Public and private, domestic and corporate: The emergence of the Southwest Asian village. American Antiquity 59: 639-666.

Campbell, M. (2006). Memory and monumentality in the Rarotongan landscape. Antiquity 80: $102-117$.

Carballo, D. M. (2011). Advances in the household archaeology of highland Mesoamerica. Journal of Archaeological Research 19: 133-189.

Carpenter, L., Feinman, G., and Nicholas, L. (2012). Spindle whorls from El Palmillo: Economic implications. Latin American Antiquity 23: 381-400.

Carson, M. T. (2002). Tī ovens in Polynesia: Ethnological and archaeological perspectives. The Journal of the Polynesian Society 111: 339-370.

Carsten, J., and Hugh-Jones, S. (eds.) (1995). About the House: Lévi-Strauss and Beyond, Cambridge University Press, Cambridge.

Chapman, R. (2003). Archaeologies of Complexity, Routledge, London.

Clark, J. T., and Herdrich, D. J. (1993). Prehistoric settlement system in Eastern Tutuila, American Samoa. Journal of the Polynesian Society 102: 147-185.

Cordy, R. H. (1981). A Study in Prehistoric Social Change: The Development of Complex Societies in the Hawaiian Islands, Academic Press, New York.

Conte, E., and Molle, G. (2014). Reinvestigating a key site for Polynesian prehistory: New results from the Hane dune site, Ua Huka (Marquesas). Archaeology in Oceania 49: 121-136.

Coupland, G. (2013). Household archaeology of complex hunter-gatherers on the northwest coast of North America. In Medella, M., Kovacs, G., Berzsenyi, B., and Briz, I. (eds.), Archaeology of Household, Oxbow Books, Oxford, pp. 45-66.

Crosby, A. (2004). Ritual. In Furey, L., and Holdaway, S. (eds.), Change Through Time: 50 Years of New Zealand Archaeology, Monograph No. 26, New Zealand Archaeological Association Auckland, pp. 105-125.

Crown, P. L. (1994). Community dynamics, site structure, and aggregation in the northern Rio Grande. In Wills, W. H., and Leonard, R. D. (eds.), The Ancient Southwestern Community: Models and Methods for the Study of the Prehistoric Social Organization, University of New Mexico Press, Albuquerque, pp. 103-117.

D’Altroy, T. N., and Hastorf, C. A. (2001). Empire and Domestic Economy, Plenum, New York.

Davies, J. (1851). A Tahitian and English Dictionary with Introductory Remarks on the Polynesian Language and a Short Grammar of the Tahitian Dialect with an Appendix, 2nd ed., Haere Po No Tahiti, Papeete.

Davidson, J. M. (1974a). Samoan structural remains and settlement patterns. In Green, R. C., and Davidson, J. M. (eds.), Archaeology in Western Samoa, Vol. 2, Bulletin of the Auckland Institute and Museum 7, Auckland, NZ, pp. 225-244.

Davidson, J. M. (1974b). Test excavations in the Falefa Valley. In Green, R. C., and Davidson, J. M. (eds.), Archaeology in Western Samoa, Vol. 2, Bulletin of the Auckland Institute and Museum 7, Auckland, NZ, pp. 561-613.

Deetz, J. (1982). Households: A structural key to archaeological explanation. In Wilk, R., and Rathje, W. (eds.), Archaeology of the Household: Building a Prehistory of Domestic Life, Sage Publications, Beverly Hills, CA, pp. 717-724.

De Lucia, K. (2013). Domestic economies and regional transition: Household multicrafting and lake exploitation in pre-Aztec central Mexico. Journal of Anthropological Archaeology 32: 353-367.

De Lucia, K., and Overholtzer, L. (2014). Everyday action and the rise and decline of ancient polities: Household strategy and political change in Postclassic Xaltocan, Mexico. Ancient Mesoamerica 25: $441-458$.

Dixon, B., Gossier, D., and Williams, S. S. (2008). Traditional men's houses and their socio-political context in Lualualei, Leeward West O‘ahu, Hawai'i. The Journal of the Polynesian Society 117: 267-295.

Dixon, B., Major, M., Orice, M., Carpenter, A., Stine, C., and Longton, B. (1994). Lithic Tool Production and Dryland Planting Adaptations to Regional Agricultural Intensification: Preliminary Evidence form Leeward Moloka'i, Hawai'I, Bishop Museum Occasional Papers No. 39, Bishop Museum Press, Honolulu.

Douglass, J. D. (2002). Hinterland Households: Rural Agrarian Household Diversity in Northwest Honduras, University Press of Colorado, Boulder.

Drennan, R. D., Earle, T., Feinman, G. M., Fletcher, R., Kolb, M. J., Peregrine, P., Peterson, C. E., Sinopoli, C., Smith, M. E., Smith, M. L., Stark, B. L., and Stark, M. T. (2012). Comparative 
archaeology: A commitment to understanding variation. In Smith, M. E. (ed.), The Comparative Archaeology of Complex Societies, Cambridge University Press, Cambridge, pp. 1-3.

Drennan, R. D., and Peterson, C. E. (2006). Patterned variation in prehistoric chiefdoms. Proceedings of the National Academy of Sciences USA 103: 3960-3967.

Drennan, R. D., and Peterson, C. E. (2011). Challenges for comparative study of early complex societies. In Smith, M. E. (ed.), The Comparative Archaeology of Complex Societies, Cambridge University Press, Cambridge, pp. 62-87.

Dueppen, S. A. (2015). Expressing difference: Inequality and house-based potting in a first-millennium AD community (Burkina Faso, West Africa). Cambridge Archaeological Journal 25: 17-43.

Dumont, d'Urville, M. J. (1832). Notice sur les îles du Grand Océan et sur l'origine des peoples qui les habitant. Société de Géographie Bulletin 17: 1-21.

Dunnell, R. C. (1991). Methodological impacts of catastrophic depopulation on American archaeology and ethnology. In Thomas, D. H. (ed.), Columbian Consequences, Smithsonian Institution Press, Washington, DC, pp. 561-580.

Dye, T. (2010). Social transformations in Old Hawai'i: A bottom up approach. American Antiquity 75: $727-741$.

Earle, T. (2011). Chiefs, chieftaincies, chiefdoms, and chiefly confederacies: Power in the evolution of political systems. Social Evolution \& History 10: 27-54.

Earle, T., and Smith, M. E. (2011). Households, economies, and power in the Aztec and Inka imperial provinces. In Smith, M. E. (ed.), The Comparative Archaeology of Complex Societies, Cambridge, Cambridge University Press, pp. 238-284.

Eddowes, M. (2001). Transformation des pratiques religieuses de la fin du culte Hui Arii: Les cultes Tutae Auri et Mamaia et leur présence dans la haute vallée de la Papenoo de 1815 a 1840. Bulletin de la Société des Etudes Océaniennes 289-291: 37-75.

Emerson, T. E. (2012). Cahokia interaction and ethnogenesis in the northern midcontinent. In Pauketat, T. E. (ed.), The Oxford Handbook of North American Archaeology, Oxford University Press, Oxford, pp. 398-409.

Endicott, J. M. (2000). Archaeological and Ethnohistoric Evidence for Protohistoric Social Relations on Mangaia Island, Cook Islands, Ph.D. dissertation, Department of Anthropology, University of California, Berkeley.

Endicott, J. M. 2002 The social landscape of Mangaia, southern Cook Islands. In Ladefoged, T. N., and Graves, M. W. (eds.), Pacific Landscapes: Archaeological Approaches, Easter Island Foundation, Los Osos, CA, pp. 175-188.

Estévez Escalera, J., and Clemente-Conte, I. (2013). Domestic space: Analysis of the activities of a hunter-gatherer social unit at the southern end of the American continent. In Madella, M., Kovacs, G., Berzsenyi, B., and Godino, I. B. (eds.), The Archaeology of Household, Oxbow Books, Oxford, pp. 67-85.

Feinman, G. M. (1997). Thoughts on new approaches to combining the archaeological and historical records. Journal of Archaeological Method and Theory 4: 367-377.

Feinman, G. M., and Neitzel, J. (1984). Too many types: An overview of sedentary prestate societies in the Americas. Advances in Archaeological Method and Theory 7: 39-102.

Feinman, G. M., and Nicholas, L. M. (2012). The late prehispanic economy of the Valley of Oaxaca, Mexico: Weaving threads from data, theory, and subsequent history. In Matejowsky, T., and Wood, D. C. (eds.), Political Economy, Neoliberalism, and the Prehistoric Economies of Latin America, Research in Economic Anthropology, Vol. 32, Emerald, Bingley, U. K., pp. 225-258.

Field, J. S., Kirch, P. V., Kawelu, K., and Ladefoged, T. N. (2010). Households and hierarchy: Domestic modes of production in Leeward Kohala, Hawai'i Island. Journal of Island and Coastal Archaeology 5: 52-85.

Field, J. S., Ladefoged, T. N., and Kirch, P. V. (2011). Household expansion linked to agricultural intensification during emergence of Hawaiian archaic states. Proceedings of the National Academy of Sciences USA 108: 7327-7332.

Firth, R. (1957). We, the Tikopia: A Sociological Study of Kinship in Primitive Polynesia, 2nd ed., American Book Co., New York.

Flannery, K. V. (ed.) (1976). The Early Mesoamerican Village, Academic Press, New York.

Flannery, K. V., and Marcus, J. (2005). Excavations at San José Mogote 1: The Household Archaeology, Memoirs No. 40, Museum of Anthropology, University of Michigan, Ann Arbor. 
Flexner, J. L. (2010). Archaeology of the Recent Past at Kalawao: Landscape, Place, and Power in a Hawaiian Leprosarium, Ph.D. dissertation, Department of Anthropology, University of California, Berkeley.

Fowler, C. (2004). The Archaeology of Personhood, Routledge, London.

Fowles, S. (2010). The Southwest School of landscape archaeology. Annual Review of Anthropology 39: $453-468$.

Fox, J. J. (1995). Austronesian societies and their transformations. In Bellwood, P., Fox, J. J., and Tryon, D. (eds.), The Austronesians: Historical and Comparative Perspectives, Australian National University, Canberra, pp. 229-240.

Fox, J. J. (ed.) (1993). Inside Austronesian Houses: Perspectives on Domestic Designs for Living, Australian National University, Canberra.

Frankel, D., and Webb, J. M. (2006). Neighbours: Negotiating space in a prehistoric village. Antiquity 80: 287-302.

Furey, L. (1996). Oruarangi: The Archaeology and Material Culture of a Hauraki Pa, Bulletin 17, Auckland Institute and Museum, Auckland.

Goldman, I. (1970). Ancient Polynesian Society, University of Chicago Press, Chicago.

Gould, R. A. (1980). Living Archaeology, Cambridge Press, Cambridge.

Green, R. C. (1967). Settlement patterns: Four case studies from Polynesia. In Solheim, W. G. II (ed.), Archaeology at the Eleventh Pacific Science Congress, Asian and Pacific Archaeology Series 1, Social Science Research Institute, University of Hawaii, Honolulu, pp. 101-132.

Green, R. C. (1980). Makaha Before 1880 AD, Pacific Anthropological Records 31, Department of Anthropology, Bernice P. Bishop Museum, Honolulu.

Green, R. C. (1984). Settlement pattern studies in Oceania: An introduction to a symposium. New Zealand Journal of Archaeology 6: 59-69.

Green, R. C. (1986). Some basic components of the Ancestral Polynesian settlement system: Building blocks for more complex Polynesian societies. In Kirch, P. V. (ed.), Island Societies, Archaeological Approaches to Evolution and Transformation, Cambridge University Press, Cambridge, pp. 50-54.

Green, R. C. (1996). Settlement patterns and complex society in the Windward Society Islands: Retrospective commentary from the 'Opunohu Valley, Mo'orea. In Julien, M., Orliac, M., and Orliac, C. (eds.), Mémoire de Pierre, Mémoire d'homme: tradition et archéologie en Océanie, Publications de la Sorbonne, Paris, pp. 209-228.

Green, R. C. (2002). A retrospective view of settlement pattern studies in Samoa. In Ladefoged, T. N., and Graves, M. W. (eds.), Pacific Landscapes: Archaeological Approaches, Easter Island Foundation, Los Osos, CA, pp. 125-152.

Green, R. C., and Davidson, J. M. (eds.) (1969). Archaeology in Western Samoa, Bulletin 7, Vol. 1, Auckland Institute and Museum, Auckland.

Green, R. C., and Davidson, J. M. (eds.) (1974). Archaeology in Western Samoa, Bulletin 7, Vol. 2, Auckland Institute and Museum, Auckland.

Green, R. C., Green, K., Rappaport, Roy A. Rappaport, A., and Davidson, J. M. (1967). Archeology on the Island of Mo'orea, French Polynesia, Anthropological Papers Vol. 1, Part 2, American Museum of Natural History, New York, pp. 111-230.

Guengerich, A. (2014). The architect's signature: The social production of a residential landscape at Monte Viudo, Chachapoyas, Peru. Journal of Anthropological Archaeology 34: 1-16.

Guerrero, E., Molist, M., Kuijt, I., and Anfruns, J. (2009). Seated memory: New insights into Near Eastern Neolithic mortuary variability from Tell Halula, Syria. Current Anthropology 50: 379-391.

Gumerman, G. IV. (2010). Big hearths and big pots: Moche feasting on the north coast of Peru. In Klarich, E. (ed.), Inside Ancient Kitchens, University Press of Colorado, Boulder, pp. 111-132.

Handy, E. S. (1923). The Native Culture in the Marquesas, Bernice P. Bishop Museum Bulletin 9, Bishop Museum Press, Honolulu.

Handy, E. S. (1932). Houses, Boats, and Fishing in the Society Islands, Bernice P. Bishop Museum Bulletin 90, Bishop Museum Press, Honolulu.

Handy, E. S., and Pukui, M. K. (1972) The Polynesian Family System in Ka-u, Hawai'I, Tuttle, Rutland. Hamilton, S. (2013). Rapa Nui (Easter Island)'s stone worlds. Archaeology International 16: 96-109.

Hamilton, B., and Kahn, J. G. (2007). Pre-contact population in the 'Opunohu Valley, Mo'orea: An integrated archaeological and ethnohistorical approach. In Kirch, P. V., and Rallu, J.-L. (eds.), The Growth and Collapse of Pacific Island Societies: Archaeological and Demographic Perspectives, University of Hawai'i Press, Honolulu, pp. 129-159. 
Harris, O. J., and Robb, J. (2012). Multiple ontologies and the problem of the body in history. American Anthropologist 114: 668-679.

Hendon, J. (1996). Archaeological approaches to the organization of domestic labor: Household practice and domestic labor. Annual Review of Anthropology 25: 45-61.

Hendon, J. A. (1999). The Pre-Classic Maya compound as the focus of social identity. In Grove, D. C., and Joyce, R. (eds.), Social Patterns in Pre-Classic Mesoamerica, Dumbarton Oaks, Washington, DC, pp. $97-125$.

Hendon, J. (2004). Living and working at home: The social archaeology of household production and social relations. In Meskell, L., and Preucel, R. W. (eds.), A Companion to Social Archaeology, Blackwell, Oxford, pp. 272-286.

Hendon, J. A. (2010). Houses in a Landscape: Memory and Everyday Life in Mesoamerica, Duke University Press, Durham, NC.

Hendren, G. H. (1975). Excavation of eight inland prehistoric habitation sites. In Kirch, P. V., and Kelley, M. (eds.), The Prehistory and Ecology of a Windward Hawaiian Valley: Halawa Valley, Molokai, Pacific Anthropological Records 24, Department of Anthropology, Bernice P. Bishop Museum, Honolulu, pp. 117-152.

Herrmann, V. R. (2011). The empire in the house, the house in the empire: Toward a household archaeology perspective on the Assyrian Empire in the Levant. In Yasur-Landau, A., Ebeling, J. R., and Mazow, L. B. (eds.), Household Archaeology in Ancient Israel and Beyond, Koninklijke Brill, Leiden, pp. 303-320.

Hirth, K. (2013). Economic consumption and domestic economy in Cholula's rural hinterland, Mexico. Latin American Antiquity 24: 123-148.

Holdaway, S., and Wallace, R. (2013). A materialisation of social organization: The 19th century occupation of Te Oropuriri, Taranaki, New Zealand. In Campbell, M., Holdaway, S., and Macready, S. (eds.), Finding Our Recent Past: Historical Archaeology in New Zealand, Monograph No. 29, New Zealand Archaeological Association, Auckland, pp. 77-96.

Holmer, R. N. (1980). Mt. Olo settlement pattern interpretation. In Jennings, J. D., and Holmer, R. N. (eds.), Archaeological Investigations in Western Samoa, Pacific Anthropological Records 32, Department of Anthropology, Bernice P. Bishop Museum, Honolulu, pp. 93-103.

Hommon, R. J. (2013). The Ancient Hawaiian State, Oxford University Press, Oxford.

Horrocks, M., and Wozniak, J. A. (2008). Plant microfossil analysis reveals disturbed forest and a mixedcrop, dryland production system at Te Niu, Easter Island. Journal of Archaeological Science 35: $126-142$.

Hutson, S. R., and Welch, J. A. (2014). Sacred landscapes and building practices at Uci, Kancab, and Anducanha, Yucatan, Mexico. Ancient Mesoamerica 25: 421-439.

Inomata, T. (2001). The power and ideology of artistic creation: Elite craft specialists in Classic Maya society. Current Anthropology 42: 321-349.

Inomata, T., and Stiver, L. R. (1998). Floor assemblages from burned structures at Aguateca, Guatemala: A study of Classic Maya households. Journal of Field Archaeology 25: 431-452.

Irwin, G. (ed.) (2004). Kohika: The Archaeology of a Late Maori Lake Village in the Ngati Awa rohe, Bay of Plenty, New Zealand, Auckland University Press, Auckland.

Ishizuki, K. (1974). Excavation of site SU-FO-1 at Folasa-A-Lalo. In Green, R. C., and Davidson, J. M. (eds.), Archaeology in Western Samoa, Vol. 2, Bulletin 7, Auckland Institute and Museum, Auckland, pp. 36-57.

Jacomb, C. (2005). A fourteenth-century house from the Rakaia River Mouth, Canterbury, New Zealand. Archaeology in Oceania 40: 91-105.

Janusek, J. W. (2004). Collapse as cultural revolution: Power and identity in the Tiwanaku to Pacajes transition. In Vaughn, K. J., Ogburn, D, and Conlee, C. A. (eds.), Foundations of Power in the Prehispanic Andes, Archeological Papers No. 14, American Anthropological Association, Vol. 14, pp. 175-209.

Janusek, J. W. (2005). Residential diversity and the rise of complexity in the south-central Andes. In Stanish, C., Cohen, A. B., and Aldenderfer, M. S. (eds.), Advances in Titicaca Basin Archaeology, Vol. 1, Costen Institute of Archaeology, Los Angeles, pp. 143-172.

Jennings, J. D., and Holmer, R. N. (eds.) (1980). Archaeological Excavations at Western Samoa, Pacific Anthropological Records 32, Department of Anthropology, Bernice P. Bishop Museum, Honolulu.

Jennings, J. D., Holmer, R. N., Janetski, J., and Smith, H. L. (1976). Excavations at Upolu, Western Samoa, Pacific Anthropological Records 25, Department of Anthropology, Bernice P. Bishop Museum, Honolulu. 
Jennings, J. D., Holmer, R. N., and Jackmond, G. (1982). Samoan village patterns: Four examples. Journal of the Polynesian Society 91: 81-102.

Jonassen, J. (1994). Are Kariei: The Cook Islands house of entertainment. In Stephanson, R. (ed.), Traditional Technological Structures and Cultures of the Pacific: Five Papers, University of Guam Press, Mangilao, pp. 18-31.

Joyce, A. A., Bustamente, L. A., and Levine, M. N. (2001). Commoner power: A case study from the Classic period collapse on the Oaxaca coast. Journal of Archaeological Method and Theory 8: 343-385.

Joyce, R. A. (2000). Heirlooms and houses: Materiality and social memory. In Joyce, R. A., and Gillespie, S. D. (eds.), Beyond Kinship: Social and Material Reproduction in House Societies, University of Pennsylvania Press, Philadelphia, pp. 1-28.

Junker, L. L. (2001). The evolution of ritual feasting systems in prehispanic Phillipine chiefdoms. In Hayden, B. (ed.), Feasts: Archaeological and Ethnographic Perspectives on Food, Politics, and Power, Smithsonian Institution Press, Washington, DC, pp. 267-310.

Kahn, J. G. (2003). Maohi social organization at the micro-scale: Household archaeology in the 'Opunohu Valley, Mo'orea, Society Islands (French Polynesia). In Sand, C. (ed.), Pacific Archaeology: Assessments and Prospects, Le Cahiers de l'Archéologie en Nouvelle-Calédonie z15, Départmente Archéologie, Service des Musées et du Patrimoine de Nouvelle-Calédonie, Nouméa, pp. 353-367.

Kahn, J. G. (2005). Household and Community Organization in the Late Prehistoric Society Island Chiefdoms (French Polynesia), Ph.D. dissertation, Department of Anthropology, University of California, Berkeley.

Kahn, J. G. (2007). Power and precedence in ancient house societies: A case study from the Society Island chiefdoms (French Polynesia). In Beck, R. (ed.), The Durable House: House Society Models in Archaeology, Occasional Paper No. 35, Center for Archaeological Investigations, Southern Illinois University, Carbondale, pp. 198-223.

Kahn, J. G. (2008). Ritual house posts and "house societies" in Polynesia: Modeling inter- and intrahousehold variability. Rapa Nui Journal 22: 14-29.

Kahn, J. G. (2011). Multi-phase construction sequences and aggregate site complexes of the prehistoric Windward Society Islands (French Polynesia). Journal of Island and Coastal Archaeology 6: 24-50.

Kahn, J. G. (2014a). Colonization, settlement, and process in central Eastern Polynesia. In Hunt, T., and Cochrane, R. (eds.), Handbook of Prehistoric Oceania, Oxford Press, Oxford, pp. 1-11.

Kahn, J. G. (2014b). Household archaeology and 'house societies' in the Hawaiian archipelago. Journal of Pacific Archaeology 5: 18-29.

Kahn, J. G. (2015). Identifying residences of ritual practitioners in the archaeological record as a proxy for social complexity. Journal of Anthropological Archaeology 40: 59-81.

Kahn, J. G., and Coil, J. (2006). What house posts tell us about status difference in prehistoric Tahitian society: An interpretation of charcoal analysis, sacred woods and inter-site variability. The Journal of the Polynesian Society 115: 319-352.

Kahn, J. G., Dotte-Sarout, E., Molle G., and Conte, E. (2015a). Landscape change, settlement histories, and agricultural practices on Maupiti Island, Society Island Archipelago. Journal of Island and Coastal Archaeology. DOI: 10.1080/15564894.2014.1001922.

Kahn, J. G., Horrocks, M., and Nieuwoudt, M. (2014). Agriculture, domestic production, and site function: Micro-fossil analyses and late prehistoric landscapes of the Society Islands. Economic Botany 68: 246-263.

Kahn, J. G., and Kirch, P. V. (2004). Ethnographie préhistorique d'une "société à maisons" dans la Vallée de 'Opunohu (Mo'orea, Iles de la Société). Journal de la Société des Océanistes 119: 229-256.

Kahn, J. G., and Kirch, P. V. (2011). Monumentality and the materialization of ideology in Central Eastern Polynesia. Archaeology in Oceania 46: 93-104.

Kahn, J. G., and Kirch, P. V. (2013). Residential landscapes and house societies of the late prehistoric Society Islands (French Polynesia). Journal of Pacific Archaeology 4: 50-72.

Kahn, J. G., and Kirch, P. V. (2014). Monumentality and Ritual Materialization in the Society Islands, Bulletin in Anthropology 13, Bishop Museum Press, Honolulu.

Kahn, J. G., Nickelsen, C., Stevenson, J., Porch, N., Dotte-Sarout, E., Christensen, C. C., May, L., Athens, J. S., and Kirch, P. V. (2015b). Mid- to late Holocene landscape change and anthropogenic transformations on Mo'orea, Society Islands: A multi-proxy approach. The Holocene 25: 333-347. 
Kahn, J. G., and Ragone, D. (2013). Identification of carbonized breadfruit (Artocarpus altilis) skin: Refining site function and site specialization in the Society Islands, East Polynesia. Journal of Ethnobiology 33: 237-258.

Kahn, J. G., Sinton, J., Mills, P. R., and Lundblad, S. P. (2013). X-ray fluorescence analysis and intraisland exchange in the Society Island archipelago. Journal of Archaeological Science 40: 1194-1202.

Keith, K. (1998). Spindle whorls, gender, and ethnicity at Late Chalcolithic Hacinebi Tepe. Journal of Field Archaeology 25: 497-515.

King, S. M. (2008). The spatial organization of food sharing in Early Postclassic households: An application of soil chemistry in ancient Oaxaca, Mexico. Journal of Archaeological Science 35: 1224-1239.

Kirch, P. V. (1985). Feathered Gods and Fishhooks: An Introduction to Hawaiian Archaeology and Prehistory, University of Hawaii Press, Honolulu.

Kirch, P. V. (1996). Tikopia: Social space revisited. In Davidson, J. M., Irwin, G., Leach, F., Pawley, A., and Brown, D. (eds.), Oceanic Culture History: Essays in Honour of Roger Green, New Zealand Journal of Archaeology Special Publication, Dunedin, pp. 257-274.

Kirch, P. V. (1998). Landscapes of power: Late prehistoric settlement and land use of marginal environments in the Hawaiian Islands. In Vargas Casanova, P. (ed.), Easter Island and East Polynesian Prehistory, Proceedings of the Second International Congress on Easter Island and East Polynesian Archaeology, Universidad de Chile, Santiago, pp. 59-72.

Kirch, P.V. (2000). On the Road of the Winds, University of California Press, Berkeley.

Kirch, P. V. (2001). Polynesian feasting in ethnohistoric, ethnographic, and archaeological contexts: A comparison of three societies. In Dietler, M., and Hayden, B. (eds.), Feasts: Archaeological and Ethnographic Perspectives of Food, Politics, and Power, Smithsonian Institute Press, Washington, DC, pp. 168-184.

Kirch, P. V. (2010). How Chiefs Became Kings, University of California Press, Berkeley.

Kirch, P. V. (2011). When did Polynesians settle Hawai'i: A review of 150 years of scholarly inquiry and a tentative answer. Hawaiian Archaeology 12: 3-26.

Kirch, P. V. (2014). Kua'aina Kahiko: Life and Land in Ancient Kahikinui, Maui, University of Hawai 'i Press, Honolulu.

Kirch, P. V., and Green, R. C. (2001). Hawaiki, Ancestral Polynesia: An Essay in Historical Anthropology, Cambridge University Press, Cambridge.

Kirch, P. V., and Kelly, M. (eds.) (1975). Prehistory and Ecology in a Windward Hawaiian Valley: Halawa Valley, Molokai, Pacific Anthropological Records 24, Department of Anthropology, Bernice P. Bishop Museum, Honolulu.

Kirch, P. V., Millerstrom, S., Jones, S., and McCoy, M. D. (2010). Dwelling among the gods: A late precontact priest's house in Kahikinui, Maui, Hawaiian Islands. Journal of Pacific Archaeology 1: 145-160.

Kirch, P. V., and O'Day, S. J. (2003). New archaeological insights into food and status: A case study from pre-contact Hawaii. World Archaeology 34: 484-497.

Kirch, P. V., and Rallu, J.-L. (2007). The Growth and Collapse of Pacific Island Societies: Archaeological and Demographic Perspectives, University of Hawaii Press, Honolulu.

Kirch, P. V., and Sahlins, M. (1992a). Anahulu: The Anthropology of History in the Kingdom of Hawaii, Vol. 1: Historical Ethnography, University of Chicago Press, Chicago.

Kirch, P. V., and Sahlins, M. (1992b). Anahulu: The Anthropology of History in the Kingdom of Hawaii, Vol. 2: The Archaeology of History, University of Chicago Press, Chicago.

Klieger, P. C., and Lebo, S. A. (1999). Phase II archaeology survey at Moku 'ula: King Kamehameha III's royal residence, Lahaina, Maui. Report prepared for the Friends of Moku'ula, Lahaina, Maui. Retrieved from http://www.mokuula.com/archive/survey1999.php.

Knight, V. J., Jr. (2004). Characterizing elite midden deposits at Moundville. American Antiquity 69: 304-321.

Kolb, M. J. (1999). Staple finance, ritual pig sacrifice, and ideological power in ancient Hawai'i. In Bacus, E. A., and Lucero, L. J. (eds.), Complex Polities in the Ancient Tropical New World, Archeological Papers No. 9, American Anthropological Association, Arlington, VA, pp. 89-107.

Kolb, M. J. (2012). The genesis of monuments in island societies. In Smith, M. E. (ed.), The Comparative Archaeology of Complex Societies, Cambridge University Press, Cambridge, pp. 138-164. 
Kovács, G. (2013). Soil micromorphology of the household at Százhalombatta-Földvár Bronze Age tell Settlement, Hungary. In Madella, M., Kovacs, G., Berzsenyi, B., and Godino, I. B. (eds.), The Archaeology of Household, Oxbow Books, Oxford, pp. 179-216.

Kristiansen, K. (2013). Households in context. cosmology, economy and long-term change in the Bronze Age of northern Europe. In Madella, M., Kovacs, G., Berzsenyi, B., and Godino, I. B. (eds.), The Archaeology of Household, Oxbox Books, Oxford, pp. 235-268.

Ladefoged, T. N. (1991). Hawaiian architectural transformations during the early historic era. Asian Perspectives 30: 57-69.

Ladefoged, T. N. (1998). Spatial similarities and change in Hawaiian architecture: The expression of ritual offering and kapu in luakini heiau, residential complexes, and houses. Asian Perspectives 37: 59-73.

Ladefoged, T. N., Somers, G. F., and Lane-Hamasaki, M. M. (1987). Settlement Pattern Analysis of a Portion of Hawaii Volcanoes Park: Archaeology at Hawaii Volcanoes National Park, Publications in Anthropology No. 44, Western Archeological and Conservation Center, Tucson, AZ.

Law, R. G. (1999). Pits long, large, and prestigious: Recognition of varieties of Maori kumara storage pits northern New Zealand. New Zealand Journal of Archaeology 21: 29-45.

Lawrence, D. L., and Low, S. M. (1990). The built environment and spatial form. Annual Review of Anthropology 19: 453-505.

Leach, H. M. (2010). Did East Polynesians have a concept of luxury foods? World Archaeology 34: 442-457.

Leach, B. F., and Leach, H. M. (1979). Prehistoric Man in Palliser Bay, Bulletin 21, National Museum of New Zealand, Wellington.

Lekson, S. H. (1999). The Chaco Meridian: Centers of Political Power in the Ancient Southwest, Rowman AltaMira, Walnut Creek, CA.

Lehman, K. F., and Herdrich, D. J. (2002). On the relevance of point field spatiality in Oceania. In Bennardo, G. (ed.), Representing Space in Oceania: Culture in Language and Mind, Pacific Linguistics, Canberra, pp. 179-196.

Lepofsky, D. (2009). The past, present, and future of traditional resource and environmental management. Journal of Ethnobiology 29: 161-166.

Lepofsky, D., and Kahn, J. G. (2011). Cultivating an ecological and social balance: Elite demands and commoner knowledge in ancient Ma'ohi agriculture, Society Islands. American Anthropologist 113: 319-335.

Levine, M. N. (2011). Negotiating political economy at late postclassic Tututepec (Yucu Dzaa), Oaxaca, Mexico. American Anthropologist 113: 22-39.

Lévi-Strauss, C. (1979). Nobles sauvages. In Morazé, C., and Aron, R. (eds.), Culture, science et développement: contribution à une histoire de l'homme, Edouard Privat, Toulouse, pp. 41-55.

Lightfoot, K. G. (1995). Culture contact studies: Redefining the relationship between prehistoric and historical archaeology. American Antiquity 60: 199-217.

Lohse, J. C., and Valdez, F. M. (eds.) (2004). Ancient Maya Commoners, University of Texas Press, Austin.

Lyman, R. L., and O'Brien, M. (2001). The direct historical approach, analogical reasoning, and theory in Americanist archaeology. Journal of Archaeological Method and Theory 8: 303-342.

Macdonald, C. (ed.) (1987). De la hutte au palais: sociétés 'à maison' en Asie du sud-est insulaire, CNRS, Paris.

Malo, D. (1951). Hawaiian Antiquities, Bernice P. Bishop Special Publication 2, Bishop Museum Press, Honolulu.

Marcus, J., and Flannery, K. V. (1994). Ancient Zapotec ritual and religion: An application of the direct historical approach. In Renfrew, C., and Zubrow, E. B. (eds.), The Ancient Mind: Elements of Cognitive Archaeology, Cambridge University Press, Cambridge, pp. 55-74.

Marshall, Y. (1989). The house in northwest coast, Nuu-Chah-Nulth, society: The material structure of political action. In MacEachern, S., Archer, D. J., and Garvin, R. D. (eds.), Households and Communities: Proceedings of the Twenty-first Annual Conference of the Archaeological Association of the University of Calgary, University of Calgary, Calgary, pp. 15-21.

Marshall, Y. (1990). The excavation of N15/507: Towards a prehistory of the northern Maori semisubterranean house form. In Sutton, D. G. (ed.), The Archaeology of the Kainga: A Study of Precontact Maori Undefended Settlements at Pouerua, Northland, New Zealand, Auckland University Press, Auckland, pp. 71-98. 
Marshall, Y. (2000). Transformations of Nuu-Chah-Nulth houses. In Joyce, R. A., and Gillespie, S. D. (eds.), Beyond Kinship: Social and Material Reproduction in House Societies, University of Pennsylvania Press, Philadelphia, pp. 111-143.

Marshall, Y., and Fulton, R. (1987). Domestic plots: Computerised data management for household archaeology in New Zealand. Archaeology in Oceania 22: 112-123.

McCoy, P. C. (1973). Excavation of a rectangular house on the east rim of Rano Kau Volcano, Easter Island. Archaeology and Physical Anthropology in Oceania 8: 51-67.

McCoy, P. C. (1976). Easter Island Settlement Patterns in the Late Prehistoric and Protohistoric Periods, Easter Island Committee Bulletin 5, International Fund For Monuments, New York.

McKinnon, S. (1991). From a Shattered Sun: Hierarchy, Gender, and Alliance in the Tanimbar Islands, University of Wisconsin Press, Madison.

McKinnon, S. (1995). Houses and hierarchy: The view from a South Moluccan society. In Carsten, J., and Hughes-Jones, S. (eds.), About the House: Lévi-Strauss and Beyond, Cambridge University Press, Cambridge pp. 170-188.

McKinnon, S. (2000). The Tanimbarese tavu: The ideology of growth and the material configurations of houses and hierarchy in an Indonesian society. In Joyce, R. A., and Gillespie, S. D. (eds.), Beyond Kinship: Social and Material Reproduction in House Societies, University of Pennsylvania Press, Philadelphia, pp. 161-176.

McNiven, I, (2014). Dissolving divides: Indigenous archaeology and the quest for cultural and theoretical relevance. The TAG Antiquity Lecture 2014, Part 2. http://antiquity.ac.uk/antplus/tag/ant-lecture2014-2.

McNiven, I. J., David, B., Aplin, K., Pivoru, M., Pivoru, W., Sexton, A., Brown, J. Clarkson, C., Connell, K. Stanisic, J., Weisler, M., Haberle, S. Fairbairn, A., and Kemp, N. (2010). Historicising the present: Late Holocene emergence of a rainforest hunting camp, Gulf Province, Papua New Guinea. Australian Archaeology 71: 41-53.

Middleton, A. (2003). Maori and European landscapes at Te Puna, Bay of Islands, New Zealand, 1805-1850. Archaeology in Oceania 38: 110-124.

Middleton, A. (2007). Mission station as trading post: The economy of the church missionary society in the Bay of Islands. New Zealand Journal of Archaeology 28: 51-81.

Middleton, A. (2009). Te Puna-a New Zealand Mission Station: Historical Archaeology in New Zealand, Springer, New York.

Middleton, A. (2013). Missionization and the cult of domesticity: Local investigation of a global process. In Spencer-Wood, S. (ed.), Historical and Archaeological Perspectives on Gender Transformations: From Private to Public, Springer, New York, pp. 149-170.

Middleton, G. D. (2012). Nothing lasts forever: Environmental discourses on the collapse of past societies. Journal of Archaeological Research 20: 257-307.

Mills, P. R. (2009). Folk housing in the middle of the Pacific: Architectural lime, creolized ideologies, and expressions power in nineteenth-century Hawaii. In White, C. L. (ed.), The Materiality of Individuality: Archaeological Studies of Individual Lives, Springer, New York, pp. 75-91.

Mixter, D. W., Fulton, K. A., Bussiere, L. H., and LeCount, L. J. (2014). Living through collapse: An analysis of Maya residential modifications during the Terminal Classic period at Actuncan, Cayo, Belize. Research Reports in Belizean Archaeology 11: 55-66.

Morehart, C.T., and Helmke, C. G. (2008) Situating power and locating knowledge: A paleoethnobotanical perspective on Late Classic Maya gender and social relations. In Robin, C., and Brumfiel, E. (eds.), Gender, Households, and Society: Unraveling the Threads of the Past and the Present, Archeological Papers No. 18, American Anthropological Association, Blackwell, Malden, MA, pp. 60-75.

Morrison, A. E., and O'Conner, J. T. (2015). Settlement pattern studies in Polynesia: Past projects, current progress, and future prospects. In Cochrane, E., and Hunt, T. (eds.), The Oxford Handbook of Prehistory, DOI: 10.1093/oxfordhb/9780199925070.013.024.

Morrison, J. (1935). The Journal of James Morrison, Boatswain's Mate of the Bounty, Describing the Mutiny and Subsequent Misfortunes of the Mutineers, Together with an Account of the Island of Tahiti, Golden Cockerel Press, London.

Mulloy, W. (1965). Report 3: The fortified village of Morongo Uta. In Heyerdahl, T., and Ferdon, E. N. (eds.), Reports of the Norwegian Archaeological Expedition to Easter Island and the East Pacific, Vol. 2: Miscellaneous Papers, Monographs of the School of American Research and Kon-Tiki Museum No. 24, Part 2, Esselte AB, Stockholm. 
Nash, D. J. (2009). Household archaeology in the Andes. Journal of Archaeological Research 17: $205-261$.

Naum, M. (2012). Ambiguous pots: Everyday practice, migration and materiality. The case of medieval Baltic ware on the island of Bornholm (Denmark). Journal of Social Archaeology 12: 92-119.

Oakes, N. R. (1994). The late prehistoric Maohi fare haupape: An examination of household organization in Mo'orea, French Polynesia. M.A. thesis, Department of Archaeology, Simon Fraser University, Burnaby, BC.

O’Day, S. J. (2002). Excavations at the Kipapa rockshelter, Kahikinui, Maui, Hawai 'i. Asian Perspectives 40: $279-304$.

Orliac, C. (1982). Materiaux pour l'etude des habitations protohistoriques á Tahiti (Polynésie Française), Ph.D. dissertation, Department of Anthropology, Université de Paris I, Sorbonne.

Orliac, C. (2000). Fare et habitat à Tahiti, Editions Parenthèses, Paris.

Ossa, A. (2013). Using network expectations to identify multiple exchange systems: A case study from Postclassic Sauce and its hinterland in Veracruz, Mexico. Journal of Anthropological Archaeology 32: 415-432.

Overholtzer, L. (2015). Agency, practice, and chronological context: A Bayesian approach to household chronologies. Journal of Anthropological Archaeology 37: 37-47.

Palmer, B. (2002). Absolute spatial reference and the grammaticalisation of perceptually salient phenomena. In Bennardo, G. (ed.), Representing Space in Oceania: Culture in Language and Mind, Pacific Linguistics, Canberra, pp. 107-157.

Parmentier, R. J. (1987). The Sacred Remains: Myth, History, and Polity in Belau, University of Chicago Press, Chicago.

Pauketat, T. R. 2007. Chiefdoms and Other Archaeological Delusions, AltaMira Press, Lanham, MD.

Peterson, C. E., and Shelach, G. (2012). Jiangzhai: Social and economic organization of a Middle Neolithic Chinese village. Journal of Anthropological Archaeology 31: 265-301.

Phillips, C. (2000). Waihou Journeys: The Archaeology of 400 Years of Maori Settlement, Auckland University Press, Auckland.

Pigeot, N. (1987). La structure d'habitation C50: une occupation saisonnière a fa'ahia? Report for Département Archéologie, Centre Polynésien des Sciences Humaines, Te Anavaharau.

Pluckhahn, T. J. (2010). Household archaeology in the southeastern United States: History, trends, and challenges. Journal of Archaeological Research 18: 331-385.

Pope, M., and Pollock, S. (1995). Trade, tools, and tasks: A study of Uruk chipped stone industries. Research in Economic Anthropology 16: 227-265.

Prickett, N. (1982). An archaeologist's guide to the Maori dwelling. New Zealand Journal of Archaeology 4: $111-148$.

Quintus, S. J., and Clark, J. T. (2012). Between chaos and control: Spatial perception of domestic, political, and ritual organization in prehistoric Samoa. Journal of the Polynesian Society 131: 275-302.

Rathje, W. L., and McGuire, R. H. (1982). Rich men... Poor men. The American Behavioral Scientist 25: $705-725$.

Ravn, M. (2011). Ethnographic analogy from the Pacific: Just as analogical as any other analogy. World Archaeology 43: 716-725.

Reuter, T. A. (2002). The House of Our Ancestors: Precedence and Dualism in Highland Balinese Society, KITLV Press, Leiden.

Rieth, T. M., Mills, P. R., Lundblad, S. P., Morrison, A. E., and Johnson, A. (2013). Variation in lithic sources utilized by late pre-contact elites in Kona, Hawai'i Island. Hawaiian Archaeology 13: $103-130$.

Ritchie, N. A. (2003). Traces of the past: Archaeological insights into the New Zealand Chinese experience in southern New Zealand. In Ip, M. (ed.), Unfolding History, Evolving Identity: The Chinese in New Zealand, Auckland University Press, Auckland.

Robin, C. (2003). New directions in Classic Maya household archaeology. Journal of Archaeological Research 11: 307-356.

Robin, C. (2004). Social diversity and everyday life within Classic Maya settlements. In Hendon, J. A., and Joyce, R. A. (eds.), Mesoamerican Archaeology, Blackwell, Oxford, pp. 148-168.

Robin, C. (2006). Gender, farming, and long-term change: Maya historical and archaeological perspectives. Current Anthropology 47: 409-433.

Robin, C. (2013). Everyday Life Matters: Maya Farmers at Chan, University Press of Florida, Gainsville. 
Robin, C. (ed.) (2012). Chan: An Ancient Maya Farming Community, University Press of Florida, Gainesville.

Robin, C., and Brumfiel, E. (eds.) (2008). Gender, Households, and Society: Unraveling the Threads of the Past and the Present, Archeological Papers No. 18, American Anthropological Association, Blackwell, Malden, MA.

Rodning, C. (2009). Domestic houses at Coweeta Creek. Southeastern Archaeology 28: 1-26.

Rogers, J. D., and Smith, B. D. (eds.) (1995). Mississippian Communities and Households, University of Alabama Press, Tuscaloosa.

Rolett, B. V. (2010). Marquesan monumental architecture: Blurred boundaries in the distinction between religious and residential sites. Archaeology in Oceania 45: 94-102.

Roscoe, P. (2009). On the 'pacification' of the European Neolithic: Ethnographic analogy and the neglect of history. World Archaeology 41: 578-588.

Sahlins, M. (1958). Social Stratification in Polynesia. American Ethnological Society, Seattle.

Schwarz, K. R. (2013). Through the rearview mirror: Rethinking the Classic Maya collapse in the light of Postclassic rural social transformation. Journal of Social Archaeology 13: 242-265.

Shore, B. (1989). Mana and tapu. In Howard, A., and Borofsky, R. (eds.), Developments in Polynesian Ethnology, University of Hawaii Press, Honolulu, pp. 137-173.

Shore, B. (1996). Culture in Mind: Cognition, Culture, and the Problem of Meaning, Oxford University Press, Oxford.

Sinoto, Y. (1979). Excavations on Huahine, French Polynesia. Pacific Studies 3: 1-39.

Smith, I. W. (2002). The New Zealand Sealing Industry: History, Archaeology and Heritage Management, Department of Conservation, Wellington, NZ.

Smith, I. W. (2004). Archaeologies of identity: Historical archaeology for the 21st century. In Furey, L., and Holdaway, S. (eds.), Change through Time: 50 Years of New Zealand Archaeology, Monograph No. 26, New Zealand Archaeological Association, Auckland, pp. 251-262.

Smith, M. L. (2006). The archaeology of food preference. American Anthropologist 108: 480-493.

Spriggs, M. (2008). Ethnographic parallels and the denial of history. World Archaeology 40: 538-552.

Stahl, A. B. (1994). Change and continuity in the Banda area, Ghana: The direct historical approach. Journal of Field Archaeology 21: 181-203.

Sullivan, L. P. (1989). Household, community, and society: An analysis of Muse Creek settlements. In MacEachern, S., Archer, D. J., and Garvin, R. D. (eds.), Households and Communities, University of Calgary, Calgary, pp. 317-327.

Sutton, D. G. (1983). Huts, hovels, or houses: A clarification of prehistoric Moriori settlement patterns. In Bulmer, S. E., Law, R. G., and Sutton, D. G. (eds.), A Lot of Spadework to be Done, Monograph No. 14, New Zealand Archaeological Association, Auckland, pp. 185-211.

Sutton, D. G. (ed.) (1990a). The Archaeology of the Kainga: A Study of Precontact Maori Undefended Settlements at Pouerua, Northland, New Zealand, Auckland University Press, Auckland.

Sutton, D. G. (1990b). The Pouerua archaeological project. In Sutton, D. G. (ed.), The Archaeology of the Kainga: A Study of Precontact Maori Undefended Settlements at Pouerua, Northland, New Zealand, Auckland University Press, Auckland, pp. 13-22.

Sutton, D. G. (1990c). Conclusions: Interpretations and implications. In Sutton, D. G. (ed.), The Archaeology of the Kainga: A Study of Precontact Maori Undefended Settlements at Pouerua, Northland, New Zealand, Auckland University Press, Auckland, pp. 183-214.

Sutton, D. G. (1990d). Organization and ontology: The origins of the Maori chiefdom, New Zealand. Man 25: 667-692.

Sutton, D. G. (1993). The Archaeology of the Peripheral Pa at Pouerua, Northland, New Zealand, Auckland University Press, Auckland.

Sutton, D. G., Furey, L., and Marshall, Y. (2003). The Archaeology of the Pouerua, Auckland University Press, Auckland.

Taomia, J. (2000). Household units in the analysis of prehistoric social complexity, Cook Islands. Asian Perspectives 39: 139-164.

Trigger, B. G. (1967). The determinants of settlement patterns. In Chang, K. C. (ed.), Settlement Archaeology, National Press, Palo Alto, CA, pp. 53-78.

Tringham, R. (1988). Households, housefulls, and archaeological house remains: Social archaeology at a microscale. Plenary address at the 21st Annual Chacmool Conference, University of Calgary, Calgary, Alberta.

Tringham, R. (2012). Households through a digital lens. In Parker, B. J. and Foster, C. P. (eds.), New Perspectives in Household Archaeology, Eisenbrauns, Winona Lake, IN, pp.81-120. 
Tuggle, H. D., and Griffin, P. B. (1973). Lapakahi, Hawaii: Archaeological Studies, Asian and Pacific Studies Archaeological Series No. 5, Social Science Research Institute, University of Hawaii, Honolulu.

Ullah, I. I., Duffy, P. R., and Banning, E. B. (2015). Modernizing spatial micro-refuse analysis: New methods for collecting, analyzing, and interpreting the spatial patterning of micro-refuse from house-floor contexts. Journal of Archaeological Method and Theory 22: 1238-1262.

Ur, J. (2014). Households and the emergence of cities in ancient Mesopotamia. Cambridge Archaeological Journal 24: 249-268.

Van Gilder, C. L. (2001). Gender and household archaeology in Kahikinui, Maui. In Stevenson, C. M., Lee, G., and Morin, F. J. (eds.), Pacific 2000: Proceedings of the Fifth International Conference on Easter Island and the Pacific, Easter Island Foundation, Los Osos, CA, pp. 135-140.

Van Gilder, C. L. (2005). Families on the Land: Archaeology and Identity in Kahikinui, Maui, Ph.D. dissertation, Department of Anthropology, University of California, Berkeley.

Van Gilder, C. L., and Kirch, P. V. (1997). Household archaeology in Kipapa and Nakaohu, Kahikinui. In Kirch, P. V. (ed.), Na Mea Kahiko Kahikinui: Studies in the Archaeology of Kahikinui, Maui, Special Publication No. 1, Archaeological Research Facility, University of California, Berkeley, pp. 45-60.

Valeri, V. (1985). Kingship and Sacrifice: Ritual and Society in Ancient Hawaii, University of Chicago Press, Chicago.

Vargas Casanova, P. (1998). Rapa Nui settlement patterns: Types, function and spatial distribution of household structural components. In Vargas Casanova, P. (ed.), Easter Island and East Polynesian Prehistory, Proceedings of the Second International Congress on Easter Island and East Polynesian Archaeology, Universidad de Chile, Santiago, pp. 111-130.

Vaughn, K. J. (2004). Households, crafts, and feasting in the ancient Andes: The village context of Early Nasca craft consumption. Latin American Antiquity 15: 61-88.

Verhoeven, M. 2009. Ethnoarchaeology, analogy, and ancient society. In Pollock, S., and Bernbeck, R. (eds.), Archaeologies of the Middle East, Blackwell, Malden, MA, pp. 251-270.

Walter, R. K. (1993). The community in Ma'uke prehistory. In Graves, M. W., and Green, R. C. (eds.), The Evolution and Organization of Prehistoric Society in Polynesia, Monograph No. 19, New Zealand Archaeological Association, Auckland, pp. 72-86.

Walter, R. K. (1996). Settlement pattern archaeology in the Cook Islands. Journal of the Polynesian Society 105: 63-99.

Walter, R. K. (1998). Anai'o: The Archaeology of a Fourteenth Century Polynesian Community in the Southern Cook Islands, Monograph No. 22, New Zealand Archaeological Association, Auckland.

Walter, R. K. (2004). New Zealand archaeology and its Polynesian connections. In Furey, L., and Holdaway, S. (eds.), Change through Time: 50 Years of New Zealand Archaeology, Monograph No. 26, New Zealand Archaeological Association, Auckland, pp. 125-146.

Walter, R. K., Smith, I. W., and Jacomb, C. (2006). Sedentism, subsistence and socio-political organization in prehistoric New Zealand. World Archaeology 38: 274-290.

Waterson, R. (1990). The Living House: An Anthropology of Architecture in South East Asia, WatsonGutpill Publications, New York.

Wattenmaker, P. (1998). Crafting social identity in Ur III southern Mesopotamia. In Costin, C. L. and Wright, R. P. (eds.), Craft and Social Identity, Archeological Papers No. 8, American Anthropological Association, Arlington, VA, pp. 47-56.

Webster, J. (2008). Less beloved: Roman archaeology, slavery and the failure to compare. Archaeological Dialogues 15: 103-123.

Weisler, M. I., Collerson, K. D., Feng, Y.-X., Zhao, J.-X., and Yu, K.-F. (2006). Thorium-230 coral chronology of a late prehistoric Hawaiian chiefdom. Journal of Archaeological Science 33: 273-282.

Weisler, M. I., and Haslam, M. (2005) Determining the function of Polynesian volcanic glass artifacts: Results of a residue study. Hawaiian Archaeology 10: 1-17.

Weisler, M. I., and Kirch, P. V. (1985). The structure of settlement space at Kawela, Molokai, Hawaiian Islands. New Zealand Journal of Archaeology 7: 129-158.

Wilk, R. R., and Rathje, W. L. (1982). Archaeology of the household: Building a prehistory of the domestic life. American Behavioral Scientist 25: 641-662.

Wilmshurst, J. M., Anderson, A. J., Higham, T. F., and Worthy, T. H. (2008). Dating the late prehistoric dispersal of Polynesians to New Zealand using the commensal Pacific rat. Proceedings of the National Academy of Sciences USA 105: 7676-7680. 
Wozniak, J. A. (2003). Exploring Landscapes on Easter Island (Rapanui) with Geoarchaeological Studies: Settlement, Subsistence, and Environmental Changes, Ph.D. dissertation, Department of Anthropology, University of Oregon, Eugene.

Wright, K. I. (2014). Domestication and inequality? Households, corporate groups and food processing tools at Neolithic Çatalhöyük. Journal of Anthropological Archaeology 33: 1-33.

Yoffee, N. 1993. Too many chiefs (or safe texts for the '90s). In Yoffee, N., and Sheratt. A. (eds.), Archaeological Theory: Who Sets the Agenda? Cambridge University Press, Cambridge, pp. 60-78.

\section{Bibliography of Recent Literature}

Asaua, T. (2005). Samoan archaeology: Bridging the gap between the spoken and the scientific. M.A. thesis, Department of Anthropology, University of Auckland, Auckland.

Barnes, S. S., and Green, R. C. (2008). From Tongan meeting house to Samoan chapel: A recent Tongan origin for the Samoan Fale Āfolau. Journal of Pacific History 43: 23-49.

Bickler, S. H., MacDiarmid, T., and Baquié, B. (2011). Archaeology of Woodville, Auckland: 3D modeling of built heritage. Archaeology in New Zealand 54: 53-66.

Butcher, M., and Smith, I. W. (2010). Talking trash: Classifying rubbish-bearing deposits from colonial New Zealand sites. Journal of Pacific Archaeology 1: 53-61.

Doherty, M. (1996). Motutapu revisited. M.A. thesis, Department of Anthropology, University of Auckland, Auckland.

Flexner, J. L. (2011). Foreign animals, Hawaiian practices: Zooarchaeology in the leprosarium at Kalawao, Moloka'i, Hawaii. Journal of Pacific Archaeology 2: 82-91.

Flexner, J. L. (2012). An institution that was a village: Archaeology and social life in the Hansen's disease settlement at Kalawao, Moloka'i. Hawaii. International Journal of Historical Archaeology 16: $135-163$.

Howard, N. M. (2007). Socio-political complexity and residential settlement patterns in Vaitea, Rapa Nui. M.A. thesis, Department of Anthropology, University of Auckland, Auckland.

Irwin, G. J. (ed.) (2004). Kohika: The Archaeology of a Late Maori Lake Village in the Ngāti Awa Rohe, Bay of Plenty, New Zealand, Auckland University Press, Auckland.

Ladefoged, T. N., and Wallace, R. (2010). Excavation of an undefended site R10/494 on Motutapu Island, New Zealand. Archaeology in New Zealand 53: 170-184.

Maric, T. (2012). Dynamiques de peuplement et transformations sociopolitiques a Tahiti, Iles de la Societe, Ph.D. dissertation, Préhistoire Anthropologie Ethnologie, Université de Paris 1 Panthéon, Sorbonne.

Martinsson-Wallin, H. (2007). Samoan archaeology: A review of research history. Archaeology in Oceania 42 (Suppl.): 11-27.

Martinsson-Wallin, H. (2014). Archaeological investigations in independent Samoa: "Tala Eli" of Laupule Mound and beyond. In Martinsson-Wallin, H., and Thomas, T. (eds.), Monuments and People in the Pacific, Uppsala University, Gotland, pp. 245-272.

Middleton, A. (2010). Missionization in New Zealand and Australia: A comparison. International Journal of Historical Archaeology 14: 170-187.

Millerstrom, S. (2006). Ritual and domestic architecture, sacred places, and images: Archaeology in the Marquesas Archipelago, French Polynesia. In Lilley, I. (ed.), Archaeology of Oceania: Australia and the Pacific Islands, Blackwell, Malden, MA, pp. 284-301.

Morrison, A. (2012). An Archaeological Analysis of Rapa Nui (Easter Island, Chile), Settlement Structure: A Multi-Scalar Approach, Ph.D. dissertation, Department of Anthropology, University of Hawai 'i, Mānoa.

Mulrooney, M. A. (2012). Continuity or Collapse? Diachronic Settlement and Land Use in Hanga Ho'onu, Rapa Nui (Easter Island), Ph.D. dissertation, Department of Anthropology, University of Auckland, Auckland.

Mulrooney, M. A., Ladefoged, T. N., Stevenson, C. M., and Haoa, S. (2009). The myth of AD 1680: New evidence from Hanga Ho'onu, Rapa Nui (Easter Island). Rapa Nui Journal 23: 94-105.

Pearl, F. B., and Loiseau-Vonruff, S. (2007). Father Julien Vidal and the social transformation of a small Polynesian village (1787-1930): Historical archaeology at Massacre Bay, American Samoa. International Journal of Historical Archaeology 11: 32-59. 
Quintus, S. J. (2011). Land use and the human-environment interaction on Olosega Island, Manu'a, American Samoa. M.S. thesis, Department of Anthropology. North Dakota State University of Agriculture and Applied Science, Fargo.

Quintus, S. J., and Clark, J. T. (2012). Between chaos and control: Spatial perception of domestic, political, and ritual organization in prehistoric Samoa. Journal of the Polynesian Society 121: 275-302.

Quintus, S. J., Clark, J. T., Day, S. S., and Schwert, D. P. (2014). Investigating regional patterning in archaeological remains by pairing extensive survey with a LIDAR dataset: The case of the Manu'a Group, American Samoa. Journal of Archaeological Science: Reports DOI: 10.1016/j.jasrep.2014. 11.010 .

Scott, A. L. (2008). Houses and house society in prehistoric New Zealand. M.A. thesis, Department of Anthropology, University of Auckland, Auckland.

Vacca, K. (2014). His, hers, or theirs: The archaeology of gendered space in Hawaiian houses. In Thinking Gender 2014, UCLA Center for the Study of Women. https://escholarship.org/uc/item/ $60 \mathrm{~g} 6 \mathrm{c} 2 \mathrm{z} 2$.

Wallace, R., Irwin, G. J., and Neich, R. (2004). Houses, pataka, and wood carving at Kohika. In Irwin, G. (ed.), Kohika: The Archaeology of a Late Maori Lake Village in the Ngāti Awa Rohe, Bay of Plenty, Auckland University Press, Auckland, NZ, pp. 121-148.

Wallin, P., and Martinsson-Wallin, H. (2007). Settlement patterns: Social and ritual space in prehistoric Samoa. Archaeology in Oceania 42 (Suppl.): 83-89. 